\title{
The Euro Area's Common Pool Problem \\ Revisited: Has the Single Supervisory Mechanism Ameliorated Forbearance and Evergreening?
}

Sven Steinkamp

Aaron Tornell

Frank Westermann

Working Paper No. 107

September 2017

INSTITUTE OF EMPIRICAL ECONOMIC RESEARCH

Osnabrück University

Rolandstr. 8

49069 Osnabrück

Germany 


\title{
The Euro Area's Common Pool Problem Revisited: Has the Single Supervisory Mechanism Ameliorated Forbearance and Evergreening? ${ }^{1}$
}

\author{
Sven Steinkamp ${ }^{2}$, Aaron Tornell ${ }^{3}$, and Frank Westermann ${ }^{4}$
}

Last Revision: October 6, 2017

First Draft: September 9, 2017

\begin{abstract}
The Single Supervisory Mechanism was introduced to eliminate the common-pool problem and limit uncontrolled lending by national central banks (NCBs). We analyze its effectiveness. Second, we model how, by forbearing and providing refinancing credit, NCBs avoid domestic resolution costs and, instead, share potential losses within the Euro Area. This results in "evergreening" of bad loans. Third, we construct a new evergreening index based on a large worldwide survey administered by the ifo institute. Regressions show evergreening is significantly greater in the Euro Area and where banks are in distress. Finally, greater evergreening accompanies higher growth of NCB-credit and Target2liabilities.
\end{abstract}

Keywords: Single Supervisory Mechanism; Evergreening; Non-performing Loans; Common-pool Problem.

JEL Classification: F33; F55; E58.

We thank the ifo Institute for Economic Research for adding questions to their World Economic Survey and their support in the evaluation of the results. Aaron Tornell further thanks Potsdam University, where he was a guest scholar during this project, for their kind hospitality. Michael Bordo, Valeriya Dinger, Philip Middleton, Joe Ostroy, and Andreas Pfingsten provided helpful comments and suggestions.

2 Institute of Empirical Economic Research, Osnabrueck University, Rolandstraße 8, 49074 Osnabrück. Email: sven.steinkamp@uni-osnabrueck.de

3 Department of Economics, UC Los Angeles, 8283 Bunche Hall, Mail Stop: 147703, Los Angeles, CA 90095. Email: tornell@ucla.edu

4 Institute of Empirical Economic Research, Osnabrueck University, Rolandstraße 8, 49074 Osnabrück. Email: frank.westermann@uni-osnabrueck.de 


\section{Introduction}

Prior to 2013, national central banks (NCBs) in the Euro Area had the power to supervise domestic banks, exercised wide-ranging control over collateral eligibility and enjoyed a virtually unhindered ability to provide credit to banks. This generated a common-pool problem, as an NCB could accept as collateral potentially nonperforming loans (NPLs) from domestic banks in exchange for freshly minted Euros. By doing so, an NCB could transfer the potential losses into the balance sheet of the European Central Bank (ECB). In other words, each NCB had virtually "open access" to the fiscal resources of the entire monetary union. ${ }^{5}$

To address this situation and limit uncontrolled lending by NCBs to borderlineinsolvent banks, the ECB introduced the Single Supervisory Mechanism (SSM) in 2013.

Has this regulatory reform eliminated the common-pool problem from a de jure perspective? In practice, has it ameliorated regulatory forbearance and the associated uncontrolled NCB lending to banks?

In this paper, we address these questions by doing four things. First, we analyze the institutional details of the SSM and identify the remaining loopholes for open access. This is, to our knowledge, the first systematic analysis of the SSM's effectiveness. Second, we model a "forbearance trade-off" faced by national regulators that have open access to the resources of the monetary union. The regulator has an incentive to forbear when the banking system is in distress, as it avoids the fiscal costs of covering the bank's losses, and transfers potential future losses to the ECB. This forbearance results in "evergreening": a rollover of de facto NPLs and hence a smaller issuance of new loans. Third, we construct a new evergreening index (EG index) based on a questionnaire we designed that was administered by the Munich-based ifo Institute for Economic Research in January 2017. We use this survey-based EG index to test the model's implication that the forbearance trade-off is more acute in the Eurozone countries with banking systems in distress. Finally, we investigate whether the macroeconomic data exhibits the model's implied positive correlation between evergreening and NCB credit to banks as well as Target2 liabilities to the Eurosystem.

In the Eurozone, a bank can borrow from its NCB only if it is financially sound-i.e., it is solvent and has adequate capital - and it pledges eligible collateral. Before the reform, the ECB had no right to audit the books of the banks, but had to take at face value the statements of national regulators. The reforms gave the ECB the legal right to (i) audit the loans of all banks in the Eurozone, (ii) require recapitalization to cover shortfalls in the capital ratios and (iii) ask for provisioning against loan losses. Furthermore, if a bank fails to recapitalize, the ECB Governing Council has the power to shut it down.

As we can see, the Eurozone has achieved great progress on the regulatory front. However, some open-access loopholes remain: (i) The ECB still maintains a full-allotment policy, whereby (at a fixed interest rate, currently set at zero) banks can borrow unlimited amounts, subject to collateral eligibility; (ii) in many countries, collateral eligibility is still determined by NCBs; (iii) governments can influence the amount and quality of collateral by providing guarantees; (iv) emergency liquidity assistance (ELA) is still available, whereby countries are able to provide credit at their own discretion, even without eligible

\footnotetext{
5 At the peak of the crisis, in the summer of 2012, the NCBs of troubled countries - Greece, Italy, Ireland, Portugal, and Spain - had increased their lending to private banks by more than 1,000\%. This is an unprecedented expansion, even when compared to the Tequila and Asian crises of the 1990s.
} 
collateral $;^{6}$ and (v) accounting rules still facilitate loans to be classified as performing and maturities extended even when the chances of repayment are small. ${ }^{7}$

In sum, existing loopholes almost always allow banks to be able to pay their bills. As long as they pay their bills, they are considered solvent, which makes them eligible to borrow more from their NCB. This feedback loop makes it hard for the Single Supervisory Mechanism to have much bite.

The only real obstacle to a never-ending evergreening cycle, is the power of the ECB's Supervisory Board and the Governing Council to change the current institutional arrangements, or set bounds on individual countries. However, when we analyze the voting rules at the ECB, we find that the voting power of debtor countries makes it hard to use this option in the short-run (Section 2.4). The Banca Monte dei Paschi di Siena case illustrates how, despite the ECB's 2013 regulatory reform, the main channels of open access have remained operative (Section 2.5).

To capture this situation, we present a model where national regulators have the power to determine whether bank loans are nonperforming, in which case the bank must use its equity to cover the expected losses. When expected losses exceed equity, the regulator must bail out the bank's depositors and creditors. In this case, all of the fiscal cost is incurred domestically. If, instead, the regulator declares a share $\varphi$ of the NPLs performing, then the bank can pledge it as collateral at the NCB in exchange for newly minted Euros. A forbearance trade-off arises because, while the NCB ends up with assets that have a low repayment probability, the contingent losses will be shared with the other NCBs in the Eurozone. Thus, the country bears only a share of the cost instead of the whole bailout cost under no forbearance. $^{8}$

The newly minted Euros allow the bank to repay its creditors and to roll a share $\varphi$ of NPLs over. As a byproduct, however, the bank issues fewer new loans. Thus, forbearance results in more evergreening. In the aggregate, evergreening is positively correlated with the NCB's domestic credit creation, but negatively correlated with output growth as there is less credit available for new (profitable) projects. Furthermore, evergreening may lead to greater Target2 liabilities as bank creditors transfer the funds they receive to other countries. In other words, NPL evergreening combined with an NCB's rediscounting of such loans is the mechanism that exploits the Eurozone's common pool.

To bring the model to the data we construct a proxy for evergreening based on survey data. In this survey, we asked about 1,000 economic and financial experts over 80 countries about their opinion on several aspects of the banking system. Guided by the model, we asked experts (i) how has the bank's attitude toward awarding new loans changed between 2008 and 2017 and (ii) how its attitude toward rolling over existing loans changed. Our evergreening index (EG index) signals more evergreening if a respondent reports a more

6 While - in principle - each country is itself responsible for losses arising from ELA, this loss-sharing arrangement is not enforceable in practice. Notice that while the list of eligible collateral items (like credit claims) the NCBs can accept for refinancing operations in (ii) is determined by the ECB, each NCB decides autonomously what is acceptable under ELA, including the option to accept promissory notes.

$7 \quad$ This so-called IAS 39 standard will be replaced by the stricter IFRS 9 standard by 2018 .

8 We may term this trade-off the "Georgiou trade-off" as the situation is analogous to the one faced by Greece's chief statistician, Andreas Georgiou, who in 2009 estimated the budget deficit at 15.4\% of GDP rather than the $13.6 \%$ official estimate. The Greek Supreme Court filed charges against him for harming the national interest and causing a damage of $€ 171 \mathrm{bn}$ to domestic taxpayers, despite the European Commission's confirmation that his numbers were correct. As Georgiou commented: "It strikes me as odd, [...] that we are being prosecuted in a European Union member state for actually following European law" (Spiegel, 12 February 2013). After charges were initially dropped, the case later reopened again. In August 2017, he received a two-year suspended prison sentence. 
positive answer to the later than to the former question. That is, if it has become relatively easier to roll an old loan over than to obtain a new one.

To validate our survey-based EG index, we a construct a second EG index based on banks' balance sheet data covering Euro Area banks. This second index is increasing in the difference between the banking system's existing loans and new loans issued. We show that both indexes increase sharply after 2008 and display the same cross-country differences. To our knowledge, these two EG indexes are a novel contribution and complement the literature focused on subsidized interest rates and their effect on productivity, such as Caballero et al. (2008).

While confidential, the ifo institute allowed us to analyze the data and run regressions in their Munich headquarters. It is available there to be replicated by other researchers. In this data set, we find that experts believe that there has been a greater increase in evergreening in the Euro Area than in other countries. Furthermore, to investigate whether evergreening has been more pronounced in countries with a forbearance trade off, we ask a third question regarding the experts' assessment of banking distress in given countries. ${ }^{9}$ Regression results indicate that countries with greater distress also display greater evergreening. This result is robust to controlling for expected inflation rates, interest rates, and the general economic situation of governments and firms.

Finally, we investigate the link between evergreening and macro variables. The model predicts that an increase in evergreening should be correlated with an increase of main refinancing operations (MROs) and Target2 liabilities. We show that groups of countries with high evergreening indeed are by far the largest providers of refinancing credit within the Euro Area. Furthermore, countries displaying a strong increase in evergreening have indeed also witnessed the largest increase in Target2 liabilities.

The paper proceeds as follows. Section 2 presents an institutional analysis of the SSM and the ECB's voting rules. Section 3 contains the model of the forbearance trade-off. Section 4 presents the construction of our EG indexes and tests of the model's implications. Section 5 concludes. An appendix contains the voting rules in the different Eurosystem bodies associated with bank supervision and monetary-policy decisions.

\section{The Single Supervisory Mechanism and the Common-Pool Problem}

The common-pool problem arises in a monetary union when national authorities are able to (indirectly) access other countries' fiscal resources. In other words, there is open access. In the Euro Area, this open access played an important role in the monetary expansion since 2008. In this section, we document key institutional reforms and discuss their effectiveness in limiting NCBs' uncontrolled lending. This section can be skipped without loss of continuity. We have included it because, to our knowledge, there is no institutional analysis of the SSM and how it has ameliorated the common-pool problem in the Euro Area. The model and empirics in Sections 3 and 4 are self-contained and can be read without reference to the detailed institutional analysis of this Section. We believe, however, that such description of the extensive-form of the game is necessary to understand the roots of the non-performing loans' problem in southern Europe and the importance of the ECB's reform efforts.

\footnotetext{
9 We ask the experts about their perception of the change in nonperforming loans in their country. Unlike the credit questions, this concept is unobservable to the experts, but signals their general assessment about the true state of banking distress.
} 


\subsection{Open Access before 2013}

Before 2013, open access mainly occurred via private banks' main refinancing operations. According to the guidelines of the ECB, a bank can borrow from its national central bank (NCB) only if two conditions are satisfied: ${ }^{10}$

(1) The bank is financially sound (solvency and capital adequacy). ${ }^{11}$

(2) The bank pledges eligible collateral.

Before the reforms of 2013, the national competent authorities (NCAs) had the power to decide whether a bank was financially sound. The ECB had neither the authority to directly audit the balance sheets of critical banks nor the power to request additional capital or loan-loss provisions.

This institutional arrangement created a classic tragedy of the commons (TOC), as NCAs were comparing the marginal benefit of classifying a bank as financially soundwhich accrued entirely to the country - to its marginal cost - which they shared with the Eurozone. The marginal benefits were to avoid the resolution cost to domestic taxpayers. The marginal costs, potential losses on credit to banks, would be shared with the rest of the Eurozone according to the ECB's capital key. ${ }^{12}$

This TOC setup, which generated incentives for NCAs to forbear and classify banks as financially sound, combined with the full-allotment policy and the relaxation of collateral standards by the ECB in 2008, lead to uncontrolled central bank credit expansion. At its peak this increase reached $1,000 \%$ of central-bank credit in the crisis countries, Greece, Italy, Portugal, and Spain (GIPS).

Before October 2008, banks had to bid for a (Euro Area-wide) fixed amount of refinancing credit with a flexible interest rate. Under full allotment, in contrast, the ECB sets a fixed interest rate at which unlimited amounts of credit are available. This all-youcan-borrow-policy is still in place today, and is available to any solvent bank with eligible collateral.

In principle, the collateral requirement could become a limiting factor. However, step by step, the ECB has reduced the collateral standards. When the sovereign debt crisis hit in 2010 , the ratings were reduced further and partly abolished in majority decisions by the ECB's Governing Council. The rating thresholds have been suspended and reintroduced and then sporadically suspended again for Greece, Ireland, Portugal, and Cyprus. ${ }^{13,14,15,16}$ Thus, it was as if NCAs held a "carte blanche" from the ECB, allowing them to accept government bonds as collateral, regardless of their creditworthiness.

10 Furthermore, banks must be subject to the Eurosystem's minimum reserve requirements, must fulfill certain operational requirements, and must be subject to at least one form of official supervision (see Article 55 of $\mathrm{ECB} / 2014 / 60)$.

11 "Counterparties must be financially sound," Guideline (EU) 2015/510 of the ECB of December 2014 on the implementation of the Eurosystem monetary policy framework (ECB/2014/60), Part 3, Article 55, ECB (2015). The amending Guideline (EU) 2015/1938, Article 55a, ECB (2015), provides additional information on the rather vague concept. It clarifies that the ECB considers relevant supervising authorities' information and assessments.

12 See Article 33.2, Statutes of the ESCB

13 See ECB/2010/3. The decision was repealed on 27 February 2012 (ECB/2012/2). Later, it was accepted again conditional on provision of a buyback scheme (ECB/2012/3, ECB/2012/14).

$14 \mathrm{ECB} / 2011 / 4, \mathrm{ECB} / 2013 / 4$.

$15 \mathrm{ECB} / 2011 / 10, \mathrm{ECB} / 2013 / 4$.

$16 \mathrm{ECB} / 2013 / 13, \mathrm{ECB} / 2013 / 21, \mathrm{ECB} / 2013 / 22$. 


\section{$2.2 \quad$ The 2013 Regulatory Reforms}

By 2012, it was recognized that reform was needed to eliminate the TOC incentive structure that pervaded the Eurozone and replace it with centralized bank supervision. As the vice chair of the ECB Supervisory Board, Sabine Lautenschläger, put it, "We need a single supervisor that transcends national borders. Only then can we avoid national bias in the regulatory and supervisory treatment of banks." ${ }^{17}$

To introduce unitary decision making in the regulatory process, the Single Supervisory Mechanism (SSM) was created. The main institutional changes to achieve this goal were the following:

(1) Common regulatory standards across countries. A "single rulebook" was passed on 26 June 2013 by the European Parliament. It contains a common list of banking regulations, addressing capital ratios, liquidity, and other requirements. ${ }^{18}$ To a large extent, this rule requires banks in the Euro Area to implement the standards of the Basel III agreement. ${ }^{19}$

(2) Power to supervise. The Capital Requirements Directive (CDR4) gives the SSM the power to supervise banks in a Joint Supervisory Team (JST) and to implement EU regulation 575/2013. ${ }^{20}$

(3) Power to determine a bank's soundness. Based on this centralized supervision, financial soundness - including both solvency and capital adequacyis now decided by the ECB's Supervisory Board in Frankfurt, which includes 24 members from 18 National Competent Authorities (NCAs), typically the NCB's, and six ECB representatives.

(4) Power to close down banks. In the case of insolvency or other regulatory shortcomings, such as insufficient capital or liquidity, the Supervisory Board may recommend withdrawing a banking license. ${ }^{21}$ The final decision is then made by the ECB governing council, which is the ECB's central decision-making body and is composed of the $18 \mathrm{NCB}$ governors and six ECB executive board members. ${ }^{22}$

17 Speech by Sabine Lautenschläger at the Workshop of the European Banking Institute. Frankfurt, 27 January 2016. Transcript at http://www.ecb.europa.eu/press/key/date/2016/html/sp1601272.en.html. See also Tornell and Westermann (New York Times, 2012) for a similar argument.

18 Regulation No 575/2013 of the European Parliament and of the Council on prudential requirements for credit institutions and investment firms.

19 The European Banking Authority (EBA) - established in 2011 - has played a crucial role in developing these common standards. Its main task is to harmonize the banking regulations in Europe. Several details, such as the precise definition of Tier 1 and Tier 2 capital, for each country, or guidelines on NPL definitions, are still work in progress. Note that the EBA does not have the power to either supervise or audit a bank, unless that bank has chosen it as a supervisor.

20 Directive 2013/36/EU of the European Parliament and of the Council on access to the activity of credit institutions and the prudential supervision of credit institutions and investment firms.

21 See Article 18 of the single rulebook.

22 See Regulation (EU) No 468/2014, Article 83, ECB, 16 April 2014. 


\subsection{The Common-pool Problem in the post-reform Period}

As the previous subsection has shown, the 2013 reform has instituted a centralized supervisory regime and overall has been a step in the right direction. However, elements of the common-pool problem in the Euro Area still remain, as we describe below. In particular, there is still room for regulatory forbearance that may allow banks to classify as performing some NPLs; authorities still have the ability to prop up otherwise insolvent banks by guaranteeing their debt and keeping the NCB refinancing window open; NCBs are still able to determine what is collateral as well as the appropriate haircut.

\section{Full-Allotment Policy}

Solvency in the classical sense can hardly be in question in the presence of a full allotment policy. If a bank can borrow unlimited amounts from the NCB, it can always pay its bills. As long as it pays its bills, it is "solvent" according to most insolvency laws. However, if it is solvent, it can borrow further from the NCB. This circular loop makes it very difficult to become insolvent in the presence of a full-allotment policy.

\section{NCBs Set National Eligibility Criteria for Collateral}

The NCBs still have the de jure power to set national eligibility criteria for collateral accepted in refinancing operations (Condition (2) for borrowing from the Eurosystem). On 8 December 2011, the ECB gave permission to the NCBs to accept additional performing credit claims that satisfy specific criteria. ${ }^{23}$ Seven $\mathrm{NCBs}^{24}$ made use of this option and developed national eligibility criteria, which were approved on 9 February 2012, by the ECB Governing Council. ${ }^{25}$ Thus, in the short run, NCBs still have the power to determine what eligible collateral is.

To limit the incentives to forbear under this setting, losses arising from collateral accepted under national eligibility criteria, are de jure borne by the countries themselves. De facto, however, no country can be forced to bear any risk beyond the present value of its future seigniorage.

\section{Insufficient Haircuts}

In principle, there would be no open access via collateral if haircuts were sufficiently high. However, this is unlikely to be the case, as one can see when comparing the average haircuts taken by the ECB to those haircuts taken in the private interbank market. Drechsler et al. (2016) used this comparison to argue that an implicit collateral subsidy exists in Euro Area countries. $^{26}$

23 ECB Press conference from 8 December 2011: "Moreover, national central banks will be allowed, as a temporary solution, to accept as collateral additional performing credit claims (namely bank loans) that satisfy specific eligibility criteria. The responsibility entailed in the acceptance of such credit claims will be borne by the national central bank authorizing their use."

24 Central Bank of Ireland, Banco de España, Banque de France, Banca d'Italia, Central Bank of Cyprus, Oesterreichische Nationalbank and Banco de Portugal.

25 ECB Press release, 9 February 2012. Further details on how the national criteria deviated from the general framework can be found in Tamura and Tabakis (2013). In mid-2014, the list of idiosyncratic collateral components was extended further to encompass certain short-term debt instruments that do not satisfy the Eurosystem's general eligibility criteria for marketable assets (see ECB/2014/31, Article 5(1)).

26 Drechsler, Itamar, et al. (2016). On the distortionary effects of the Eurosystem's collateral haircuts, see also Nyborg (2017). 
Table 1 illustrates this point. For Italy, for example, government bonds accepted by the ECB have an average maturity of 16.6 years and are rated BBB- by the rating agencies. The average haircut by the ECB was $3.7 \%$ (with a minimum of $0.5 \%$ and a maximum of $7 \%$ ). In comparison, private clearing institutions in the repo market were accepting collateral from Italy with the same average maturity with an average haircut of $19.75 \%$ (with a minimum of $8 \%$ for short-term bonds and a maximum of $21.63 \%$ for long-term bonds). Thus, independent of the maturity of the bonds, the haircuts taken in the privatesector were considerably higher.

In the case of Greece, the ECB still accepted government bonds in December 2016 with an average haircut of $41.97 \%$. In contrast, the private repo markets stopped accepting Greek government bonds altogether in February 2010. In Spain, the ECB is accepting collateral not only from the central government, but also debt from autonomous Spanish regions, which have gone bankrupt and have received bailouts from the central government: Valencia ( $€ 4.5 \mathrm{bn})$, Murcia ( $€ 527 \mathrm{mn}$ ), Castilla-La Mancha ( $€ 848 \mathrm{mn})$ Canary Islands (€756.8 mn), Balearic Islands (€355 mn), and Asturias (€261.7 mn). Nevertheless, regional debt from all of these regions at the stage of writing is still accepted as collateral by the ECB.

\section{Recapitalizations}

Even if banks were to approach insolvency, national governments have the power to support their access to ECB refinancing credit by recapitalizing them. This has happened in several instances throughout the crisis. For instance, Italy recapitalized Banca Monte dei Paschi di Siena (MPS) and Spain recapitalized Bankia in 2012. ${ }^{27,28}$

Recent regulatory changes have aimed to limit this recapitalization of banks. However, in May 2017, both the ECB and the European Commission approved the recapitalization of MPS. How does this recapitalization fit into Condition (1), that NCBs may only lend to solvent banks? In a very subtle sematic arrangement, it was called a "precautionary" recapitalization because de jure the bank was still classified as "financially sound." 29

Government support for banks typically takes one of three forms: (i) a direct capital injection, (ii) a classification of tax credit as part of capital, and (iii) a guarantee of newly issued bonds.

27 See Italian Decree-Law No 87/2012.

28 See press release of the Spanish Fund for Orderly Bank Restructuring from December $26,2012$. (http://www.bde.es/f/webbde/GAP/prensa/info_interes/ficheros/frob261212en.pdf).

29 However, as part of these legislative changes, a partial bail-in (of subordinated bondholders) has become a prerequisite of a recapitalization. See the Banca D'Italia website at https://www.bancaditalia.it/ media/approfondimenti/2016/ricapitalizzazione-mps/precautionary-recapitalization-MPS.pdf?languageid=1. 
Table 1: Eligible Central Government Bonds in ESCB Refinancing Operations

Private-market Haircuts

\begin{tabular}{|c|c|c|c|c|c|c|c|c|}
\hline \multirow{3}{*}{$\begin{array}{c}\text { Issuing } \\
\text { central } \\
\text { government }\end{array}$} & \multirow{3}{*}{$\begin{array}{c}\text { Average } \\
\text { time to } \\
\text { maturity } \\
\text { (years) }\end{array}$} & \multirow{3}{*}{$\begin{array}{l}\text { Latest } \\
\text { issuer } \\
\text { rating } \\
(\mathrm{S} \& \mathrm{P}) \\
\end{array}$} & \multirow{2}{*}{\multicolumn{2}{|c|}{ ECB Haircuts }} & \multicolumn{4}{|c|}{ Private-market Haircuts } \\
\hline & & & & & LCH RepoC & Clear LTD & LCH Repo & Clear SA \\
\hline & & & $\begin{array}{c}\text { Mean } \\
(\%)\end{array}$ & $\begin{array}{c}\operatorname{Min} \& \\
\operatorname{Max}(\%)\end{array}$ & $\begin{array}{l}\text { For average } \\
\text { maturity }(\%)\end{array}$ & $\begin{array}{c}\text { Min \& } \max \\
(\%)\end{array}$ & \multicolumn{2}{|c|}{$\begin{array}{l}\text { For average Min \& } \max \\
\text { maturity }(\%) \quad(\%)\end{array}$} \\
\hline Austria & 12.0 & $\mathrm{AA}+$ & 4.25 & $0.5-7$ & 11.50 & $5.50-11.25$ & \multicolumn{2}{|c|}{ Not accepted } \\
\hline Belgium & 13.4 & $\mathrm{AA}$ & 3.59 & $0.5-7$ & 13.25 & $6.13-17.13$ & 8.00 & $0.50-19.50$ \\
\hline Canada & 3.1 & $\mathrm{AAA}$ & 1.50 & 10.5 & 6.88 & $5.5-10.50$ & \multicolumn{2}{|c|}{ Not accepted } \\
\hline Finland & 6.5 & $\mathrm{AA}+$ & 2.18 & $0.5-5$ & 7.25 & $5.50-11.50$ & \multicolumn{2}{|c|}{ Not accepted } \\
\hline France & 14.0 & $\mathrm{AA}$ & 4.41 & $0.5-7$ & 11.25 & $5.75-13.50$ & 5.50 & $0.50-15.50$ \\
\hline Germany & 9.0 & AAA & 1.86 & $0.5-5$ & 8.00 & $5.5-12.75$ & 3.25 & $0.50-15.00$ \\
\hline Greece & 9.0 & B- & 41.97 & $15-57$ & \multicolumn{2}{|c|}{ Not accepted } & \multicolumn{2}{|c|}{ Not accepted } \\
\hline Italy & 16.5 & BBB- & 3.70 & $0.5-7$ & 19.75 & $8.00-21.63$ & 22.75 & $6.00-27.75$ \\
\hline Ireland & 17.4 & $\mathrm{~A}+$ & 2.77 & $0.5-7$ & \multicolumn{2}{|c|}{ Not accepted } & \multicolumn{2}{|c|}{ Not accepted } \\
\hline Luxembourg & 10.6 & AAA & 3.10 & $10.5-5$ & 8.13 & $5.88-13.63$ & \multicolumn{2}{|c|}{ Not accepted } \\
\hline Netherlands & 10.0 & $\mathrm{AAA}$ & 4.09 & $0.5-7$ & 7.50 & $5.5-12.38$ & 5.00 & $0.50-14.75$ \\
\hline Portugal & 5.6 & $\mathrm{BB}+$ & 8.52 & $6-13$ & \multicolumn{2}{|c|}{ Not accepted } & 33.75 & $8.25-54.00$ \\
\hline Spain & 9.0 & $\mathrm{BBB}+$ & 3.66 & $0.5-7$ & 16.63 & $7.88-23.88$ & 14.75 & $2.25-35.75$ \\
\hline Sweden & 1.9 & $\mathrm{AAA}$ & 1.08 & $0.5-10.5$ & 6.25 & $5.38-11.88$ & 6.25 & $5.38-11.88$ \\
\hline
\end{tabular}




\section{Government Guarantees}

If a bank issues a new bond, this is not generally acceptable collateral at the ECB. If it were, any bank could just produce unlimited amounts of collateral by itself, and the collateral constraint would not be binding. However, as soon as the government gives a guarantee to the bonds, they become eligible collateral. In the following subsection, we will analyze this channel more closely for the MPS.

Government guarantees are not only limited to bank bonds, but can also be given to other items on a bank's asset side. With the help of guarantees, national governments can expand a bank's collateral in a critical situation. Quantitatively, this channel has been important in recent years. Currently, the Euro Area countries have $€ 167 \mathrm{bn}$. of state guarantees outstanding. ${ }^{30}$ At the peak of the crisis, it amounted to $€ 481 \mathrm{bn}$. Italy, an example of the importance of government guarantees, is discussed in more detail in the following subsection. ${ }^{31}$

\section{Emergency Liquidity Assistance}

If the ECB's Governing Council decided to no longer accept bonds of a particular countryindependent of the haircuts and state guarantees - the NCBs still have another lifeline to provide further credit to their banking institutions. While monetary policy is common in the Euro Area, the NCBs still can perform national tasks for nonmonetary policy purposes unless a two-thirds majority in the Governing Council blocks them. These nonmonetary policy activities are regulated under the ANFA agreement. ${ }^{32}$

Under ELA, NCBs design their own collateral framework and provide credit to domestic banks, at their own risk - i.e., losses are not shared with the ECB's capital key. There is no upper limit on ELA, but banks are required to repay the loans at the earliest possible instance. Thus, although unlimited, the ELA holdings are expected to exist only for a very short period. ${ }^{33}$

De facto, ELA has turned out to be one of the most important tools for preventing local banks from closing in several countries of the Euro Area. In Ireland, it was indeed a transitory solution to prevent a collapse of the domestic banking system. In other cases, however, such as Greece and Cyprus, ELA provision has become quite persistent. ${ }^{34}$

30 Note that this figure only encompasses state guarantees to private-sector institutions. Guarantees for banks that have been nationalized or partly nationalized in the wake of the crisis drop out of the statistic (e.g., Bankia).

31 Decree-Law No 201 was passed 6 December 2011 to allow the Ministry of Finance to guarantee bank bonds.

32 See Agreement on net Financial Assets (ANFA). https://www.ecb.europa.eu/ecb/legal/pdf/ en anfa agreement 19nov2014 f sign.pdf. The published ANFA agreement is dated 19 November 2014. A similar document has been in existence since the beginning of 2003 and was updated with each country joining the Euro Area, but was made public only on 3 February 2016, when a public discussion about the ANFA holdings started.

33 "A deviation is justified if, for example, it is caused [...] by an NCB's provision of Emergency Liquidity Assistance (ELA) to its banking system [...]. If this happens, the NCB has to reduce its NFA as soon as possible in order to comply again with ANFA." See https://www.ecb.europa.eu/explainers/tell-memore/html/anfa_qa.en.html.

34 Although de jure, any losses arising from ELA are not shared with the ECB's capital, de facto, loss sharing cannot be prevented when the ELA provision becomes large. Sinn and Fuest (11/13/2015, on Öknomonenstimme.org) have argued, for instance, that the countries in crisis cannot be forced to cover any losses from ELA, when the losses become larger than the present value of their future seigniorage profits. In the case of Greece, they documented that this threshold has already been far exceeded. See also, Sinn (2014). 


\section{Nonperforming Loans: The Role of Accounting Rules}

The current accounting standards in the Euro Area facilitate true nonperforming loans to be classified as performing. This, in turn, (i) allows banks to delay write offs and loan-loss provisions that reduce the capital base and (ii) enables them to use these credit claims as collateral in refinancing operations at the ECB.

The current accounting standard, IAS 39, largely follows the "incurred loss model". This provision allows banks to keep assets in their balance sheets at their $100 \%$ book value as long as the loss has not yet actually been incurred. Importantly, in the case of credit claims, banks can extend their maturities. This combination of using the incurred loss model and the ability to extend maturities clearly opens the possibility of forbearance ${ }^{35}$.

For other assets, the IAS39 includes an option to classify them as "held to maturity". Under this category, the incurred loss model can be applied as well. Indirectly, this facilitates forbearance because many credit claims are collateralized by assets, whose quality is also in doubt.

The IAS39 accounting approach is in contrast to the IFRS 9, which puts larger emphasis on the expected-loss model. Under the expected loss model, losses need to be recognized early on and assets must be valued at market prices. The IFRS 9 has been endorsed already by the European Commission and implemented by EU Regulation (No 2016/2067, 22 November 2016). However, until 2018, banks are still allowed to use IAS 39, and even after that date there are several exceptions and transition periods.

In a recent speech, ECB vice president Vítor Constâncio commented on the role of accounting rules: "The IAS 39 accounting standard (under the incurred loss approach) and the absence of guidance on write-off requirements tend to lengthen NPL write-offs in Europe." ${ }^{36}$ He also pointed out that "The powers of the banking supervisors in the EU are, however, legally limited. For instance, accounting standards, including on the imposition of provisions for nonperforming assets, are not set by supervisors." He concluded "The NPL problem has no comparable dimension in the U.S.," for structural, regulatory, and taxrelated reasons. "Differently to Europe, regulatory requirements overlay accounting standards, imposing the write-down of loans to their recoverable collateral value already after six months past due, for example."

The de facto forbearance under the new common supervision is evident when looking at the provisioning requested for NPLs. While the average private-market bid price was around $20 \%$ of the gross value, the Bank of Italy allowed banks to value bad loans at an average of $41.3 \%{ }^{37}$ Some of the NPL bundles were sold at even lower prices: at about $5 \%$. Nevertheless - due to the internal assessment chosen by the Bank of Italy - they were not excluded from being considered as collateral for further refinancing credit.

A high-level ECB working group on NPLs recently recognized these shortcomings. Referencing repeated maturity extensions, it argued: "An exposure can only be past due if there was a legal obligation to make a payment and payment is compulsory. In the event that there is no legal obligation or payment is not compulsory, nonpayment does not

35 In a recent stock-take on NPLs, the ECB recognized this: "The incurred loss approach to loan loss provisioning under IAS 39 is backward-looking (this is expected to be addressed when IFRS (International Financial Reporting Standard) 9 becomes effective in 2018) and leaves much room for judgement," ECB banking supervision, "Stocktake of national supervisory practices and legal frameworks related to NPL", September 2016.

36 Speech by Vítor Constâncio in Brussels, 3 February 2017. Transcript available at https://www.ecb.europa.eu/press/key/date/2017/html/sp170203.en.html.

37 "Italian non-performing loans in search of a price," Italy 24, 1 February 2017 (http://www.italy24. ilsole24ore.com/art/markets/2017-01-31/npls-eba-plan-131515.php?uuid=AEFFZHL and Ciavoliello et al. (2016). 
constitute a breach." ${ }^{38}$ In sum, this implies that a bank can evergreen a loan and prevent its classification as nonperforming by the supervisors and auditors.

\section{Political Pressure and Social Norms in Joint Supervisory Teams (JSTs)}

Even beyond these regulatory possibilities for open access, the new institutional structure of the SSM has some scope for open access on the grounds of political-economy considerations and social norms. In a recent speech, Sabine Lautenschläger summarized the peer effects: "European banking supervision consists not only of the ECB, but also of a total of 26 national central banks and supervisory authorities. Moreover, the national supervisors play an essential role in day-to-day supervision. They make up the majority of the members of the teams supervising the large banks. Decisions are then taken by the Supervisory Board and the ECB's Governing Council, in which the national supervisors are also represented." 39

Thus, political pressure and social norms may play a role. In the case of Italy, when the ECB Supervisory Board classified all banks as solvent, those considerations were certainly on the minds of decision makers. If the ECB Supervisory Board were to declare a bank insolvent and the Governing Council were to withdraw the bank's license, the national government may fall and new elections could destabilize the Euro Area.

\section{Small Banks are not Directly Supervised by the SSM}

The common supervision is not routinely implemented for all banks. Only the 130 largest institutions are currently directly supervised by the ECB. ${ }^{40}$ Although these institutions make up $85 \%$ of the aggregate Euro Area balance sheet, the remaining $15 \%$ are not negligible and could grow quickly in an emergency situation..$^{41}$ Currently, 3,303 banks are supervised by the NCAs, making crucial decisions on financial soundness. Even though the ECB has the de jure power to investigate the balance sheet of any bank, anytime, the smaller banks are still exposed to a TOC incentive structure. ${ }^{42}$

\subsection{Voting Power in the Eurosystem}

Despite the many channels of open access we have described, under the post-2013 regulatory framework, a country cannot keep banks solvent indefinitely by issuing further MROs in a never-ending cycle. This strategy is not costless as a country faces what we might call a shadow constraint on its contingent liabilities with the ECB. This is because the ECB has the power to vote with a simple majority in the Governing Council or the Supervisory Board of the ECB to change the current institutional arrangements. Each additional Euro

38 "Draft guidance to banks on non-performing loans," ECB banking supervision, September 2016.

39 Speech by Sabine Lautenschläger at the Workshop of the European Banking Institute. Frankfurt, 27 January 2016. Transcript at http://www.ecb.europa.eu/press/key/date/2016/html/sp1601272.en.html.

40 In exceptional cases, the ECB can also take over direct supervision of the smaller, less significant institutions (LSIs). Usually, however, the ECB only takes on an oversight function. NCAs still directly receive the reports of small and medium-sized institutions. Reporting and supervision remain in the country's national language, national accounting standards continue to apply, and the NCAs are still responsible for on-site inspections. The ECB is allowed to send observers, though.

41 See Drechsler et al. (2016), for example, show that weak capitalization is a main determinant of how much banks tap onto the Eurosystem's refinancing credit.

42 Agarwal et al. (2014), examining the US banking supervision, empirically document that central (federal) regulators are tougher than decentralized (state) regulators. 
used to prop up troubled banks raises the probability that the NCB will lose access to issue credit if a majority of the other NCBs, as well as the ECB Executive Board, deem the actions of that country excessive.

Such an intervention of the other NCBs, however, may not come very quickly due to the existing voting rules. Figure 1 illustrates the distribution of the voting power in the Eurosystem. Panel A shows the voting power of small countries relative to their GDP and capital share, respectively. While some countries are overrepresented by a factor of 10 , other countries are heavily underrepresented. The pie chart on the right illustrates that a small group of countries, representing only $1.9 \%$ of GDP, could reach a one-third blocking minority that would be sufficient to block any decision that requires a two-thirds majority or more.

The decisions taken by relevant bodies in the Euro Area are discussed in the appendix in detail. These include, in particular, four key decisions relevant to open access.

(i) Solvency: Withdrawing a banking license of systemically relevant banks requires a 50\% majority in the ECB Supervisory Board and a 50\% majority in the ECB Governing Council, and - if needed - a 50\% majority in the mediation panel.

(ii) Collateral: Regular monetary policy decisions, such as on MROs, interest rates, items on the common list of collateral, etc., require a $50 \%$ majority in the Governing Council.

(iii) Emergency Liquidity Assistance (ELA): Nonmonetary policy decisions, including ELA, can be taken unilaterally by the NCBs. A two-thirds majority in the Governing Council is necessary to block them. Although de jure without losssharing, de facto countries cannot bear the risk on their own and so it constitutes a channel of open access.

(iv) Unconventional policies: Such policies as Outright Monetary Transactions (OMT), Long-term Refinancing Operations (LTROs), and country-specific collateral rules require a two-thirds majority in the Governing Council.

In all these decisions, the power of small countries, particularly of the group of debtor countries, is quite large. Voting power is often measured by the Banzhaf power index, which indicates the likelihood of a particular country being in a pivotal position, assuming that everyone else votes randomly. Panel B of Figure 1 shows that this likelihood is quite large for Greece, Italy, Portugal and Spain (GIPS) or the Target2-debtors group. For instance, the group of Target2-debtors currently has a capital share of $62 \%$. Thus, they would not be able to introduce further unconventional policies - such as LTROs - with a two-thirds majority by themselves. Nevertheless, the likelihood that one of the TARGET2 debtor countries is part of a blocking minority to prevent potentially unwinding unconventional policies is above $80 \%$.

Because of this high influence of debtor countries in Euro Area decision making, one can infer that it is rather difficult for creditor countries to form coalitions to enforce the recapitalization of a bank, let alone withdraw its license. One should expect that the situation in a given country would need to be rather extreme for other debtor countries to agree to vote in favor of punitive measures at the supervisory board, as well as the Governing Council. 
Figure 1: Countries in crisis have a majority or blocking minority in the ECB's decision making

A) One country one vote
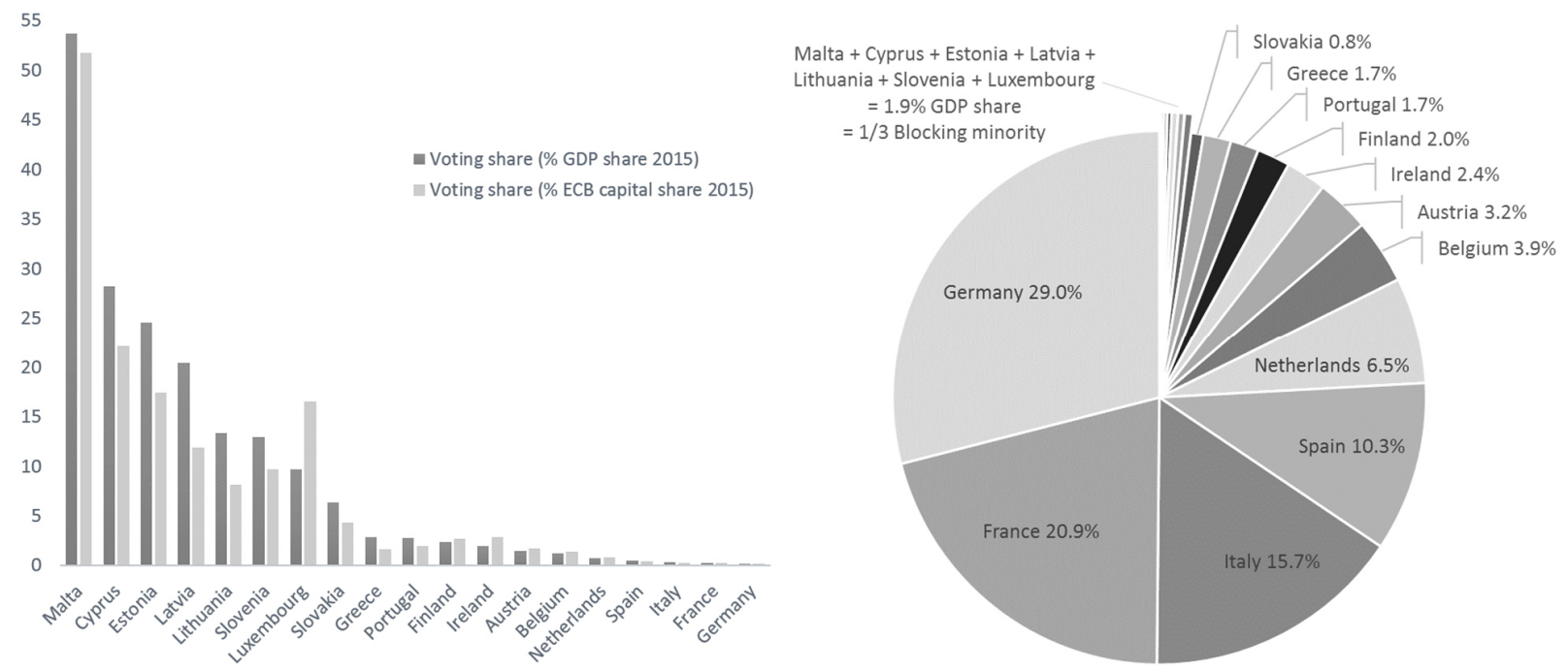

B) The power of alternative coalitions when voting by capital share (Article 10.3 decisions)

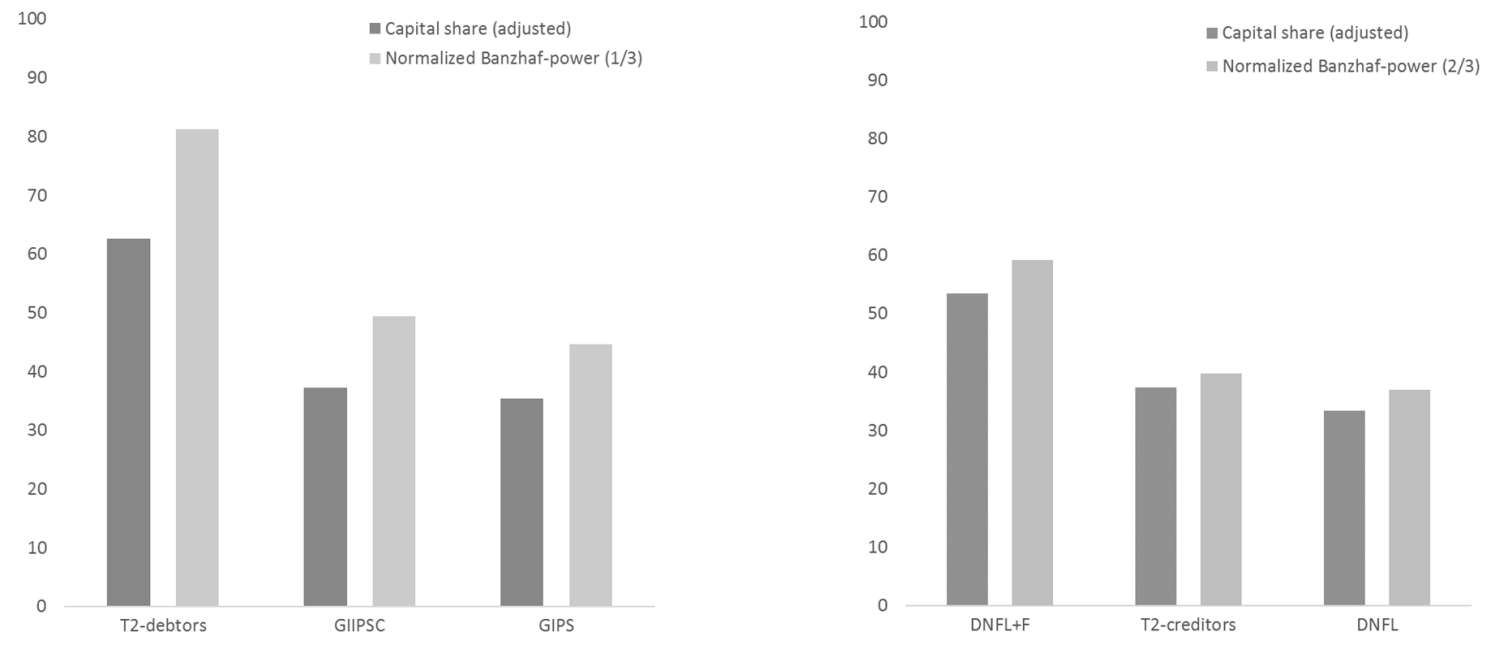

Notes: The Normalized Banzhaf power is defined as the share of possible voting coalitions in which one of the group members has the pivotal

vote relative to all possible coalitions. ECB capital shares refer to the national central banks of the Eurosystem (i.e., we account for the paid-up capital of the EU's nine non-Euro Area NCBs that are required to contribute to the ECB's operational costs without having a seat in the governing council). GI(I)PS(C) = Greece, Italy, (Ireland), Portugal, Spain, and (Cyprus). DNFL+F = Germany, the Netherlands, Finland, Luxembourg + France. Data Sources: ECB (decision ECB/2013/17), Eurostat (nama_10_gdp), authors' calculations. 


\subsection{The Case of Banca Monte dei Paschi di Siena}

The case of the Banca Monte dei Paschi di Siena (MPS) offers an interesting demonstration of how open access has help keep afloat banks on the brink of insolvency. In this subsection, we illustrate both the general situation of the Italian banking sector, and how MPS has repeatedly benefited from regulatory forbearance.

\section{General Condition in Italy}

The Bank of Italy is one of the NCBs that set national eligibility criteria for its collateral in 2011. In particular the Bank of Italy will accept credit claims that would not be eligible by the European Collateral Assessment Framework (ECAF): "In addition to the other accepted ECAF sources, bank loans' creditworthiness can be assessed according to the internal credit assessment system VALCRE run by Banca d'Italia ". ${ }^{43}$ In other words, banks whose credit portfolios where considered nonperforming by all other assessment agencies, still had the option to go the Bank of Italy and try again.

Furthermore, government guarantees played an important role in expanding the amount of eligible collateral in Italy. Just before the ECB's large expansion of central bank credit via long-term refinancing operations in 2011 (LTRO), the parliament gave permission to the ministry of finance to give state guarantees to private-bank assets and effectively expand the amount of eligible collateral.

When the first $€ 500$ bn tranche of the "Big Bazooka" was allotted to banks, the ministry of finance is reported to have used this option to extend the collateral of 14 Italian banks to borrow an additional $€ 38.4$ bn from the Bank of Italy. ${ }^{44}$ Before the second LTRO, these state guarantees skyrocketed to encompass more than 250 credit institutions - about half of all Italian banks. ${ }^{45}$

This mechanism of collateral creation still plays a key role after the regulatory reforms of $2013 .{ }^{46}$ In a new Decree Law \#237/2016 "Urgent measures for the protection of savings in the banking sector," the Italian government not only approved a capital injection - as a precautionary decision - but also activated again the possibility of giving guarantees to extend the collateral base (formally referred to as "liquidity-support measures"). This law was endorsed by an "ECB opinion" (ECB (CON/2017/1) signed by the ECB president Mario Draghi on 3 February 2017.

\section{Specific Circumstances of Banca Monte dei Paschi di Siena}

Figure 2 shows several key indicators from MPS's balance sheet since 2008. As we can see, NPLs were getting larger every year. Note that these are only the official NPLs, loans that

43 See Buiter and Rahbari (2012).

44 http://ftalphaville.ft.com/2011/12/21/809561/credit-enhancement-italian-sovereign-feedback-loop-edition/

45 According to conservative estimates, the extra collateral created still amounted to about $€ 30$ bn in August 2013 (See Nyborg, 2017)

46 In March 2015, the ECB governing council finally restricted the use of government-guaranteed own-issue bonds. As a result, guaranteed bank bonds somewhat lost their importance as collateral (see Deutsche Bundesbank, monthly report, June 2015, for details). The new Italian Decree law \#237/2016 (Article 5.4), however, circumvents this restriction by focusing on state guarantees for bank's liabilities which are not countable as "own funds." 
are officially declared more than 90 days past due. With the possibility to roll loans over, an unobserved amount of evergreened loans is likely to have existed.

In 2008, the situation appeared to have been manageable as $€ 13$ bn of NPLs were small in comparison to $€ 80$ bn of capital (broadly defined) and less than $€ 1$ bn of loans from the bank of Italy. In the course of only five years, this situation deteriorated dramatically. While NPLs were getting larger every year, the capital base was nearly cut in half and the bank had borrowed more than $€ 30$ bn from the Bank of Italy. With a common equity-to-asset ratio (a more narrow definition of capital) of just over 3\%, loans from the central bank of more than 10\% and NPLs more than 15\% of total assets, MPS was clearly a case for resolution when the ECB took over banking supervision in 2013.

After conducting its asset-quality review, the ECB indeed complained about the low capital ratio, but it did not immediately withdraw MPS's banking license. In an effort to raise capital and repay loans to the Bank of Italy, the bank appeared to make some progress in 2014 and 2015. However, during these two years, NPLs kept rising. As a result, MPS had to borrow again form the Bank of Italy to the extent of $€ 25 \mathrm{bn}$. Instead of closing the bank, the ECB still classified it as "financially sound," opening the door for another "precautionary recapitalization" by the Italian government.

Figure 2: MPS Balance Sheet

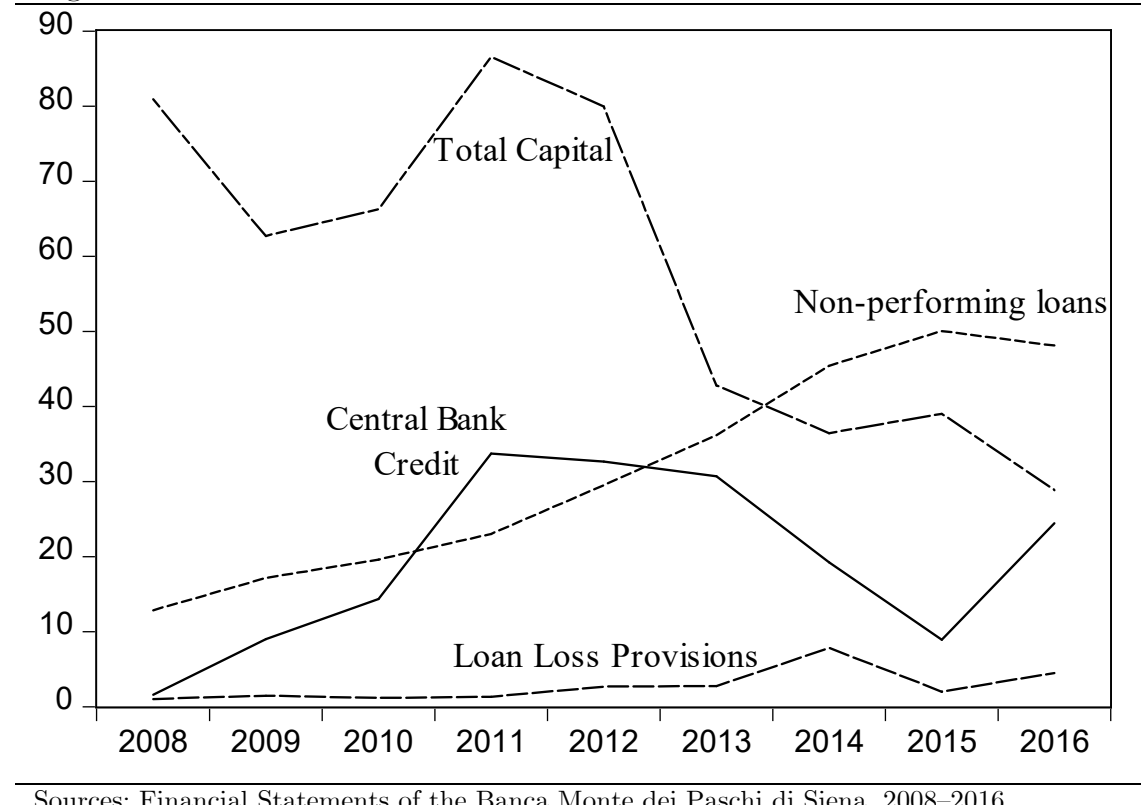

Sources: Financial Statements of the Banca Monte dei Paschi di Siena, 2008-2016.

The channels for regulatory forbearance of the ECB can partly be found in MPS's annual reports. The 2011 annual report, for instance, describes how a reclassification of assets, taking advantage of IAS 39, prevented an immediate write down of losses after the 2008 financial crisis. For example, "debt securities" held for the purpose of trading and 
recorded at fair value were reclassified as "costumer loans," held to maturity. ${ }^{47}$ The IAS 39 incurred-loss model enabled the bank to keep the working hypothesis that these claims where performing, unless a "trigger event" proves this hypothesis wrong. Only lately, as documented in the annual report of 2016, has MPS gradually returned to the IFRS expected-loss model that will be required from 2018 onwards for all banks.

Furthermore, the MPS has repeatedly taken advantage of the ECB's unconventional policies, as well as government guarantees from the Ministry of Finance. In its annual report of 2011, it is stated, "Deposits from central banks include EUR 29,000 mln [...] for long-term refinancing operations (LTROs), [...] guaranteed by securities pledged by the Parent Company (which include government-backed securities issued and simultaneously repurchased by the Parent Company for EUR 13,000 mln)." In other words, new bonds were issued and, without even being traded in the market, got a guarantee form the Ministry of Finance, and where subsequently used as collateral to obtain fresh money from the Bank of Italy.

In principle, this type of circular financing, where blank pages of paper with a "stamp" can be converted into real money, should have been stopped, both by the ECB's supervisory board in Frankfurt and by the new bail-in laws in case of bank failures. However, in 2017, MPS again took advantage of a similar operation, as documented on its latest annual report: "The Group's liquidity situation stabilized following the approval of Law Decree no. 237 (Chapter 1) of 23 December 2016, whereby the Ministry of Treasury laid out a series of Italian-bank liquidity-support measures, including the government guarantee on bond issues (Government Guaranteed Bonds)." It further clarified that "In January 2017, the Parent Company completed the first two issues of government backed securities pursuant to Law Decree no. 237/2016, for a total amount of $€ 7 \mathrm{bn}$. The securities, backed by the government guarantee pursuant to Law Decree no. $237 / 2016$, were subscribed in full by the issuer. In February, the above-mentioned securities were used in full in sales transactions in the market and as collateral to back funding transactions."

Clearly, the loophole of the 2011 circular collateral creation remains open, despite common supervision and the bailout laws. The $€ 7$ bn created by the joint activities of the Ministry of Finance and the central bank, were about $3 \%$ of total assets and thus about as large as the remaining true (paid-up) capital base, also barely above $3 \%$.

Despite this liquidity support, MPS was still on a downward trend. The inevitable recapitalization occurred in May 2017. As discussed above, it was possible only because the SSM - even after all the previous events - classified the MPS as financially sound.

As a thought experiment: Suppose the SSM had actually withdrawn MPS's license. On the same day, the bank would have had to repay its loans to the ECB. Since it almost certainly could not, the Italian government would have had to step in and pay the part for which it provided guarantees. Knowing the fragile state of Italian public finances, it is easy to imagine the political pressures that must have existed just prior to the most recent bailout.

47 The report states that "In the course of 2008, the Group applied the amendment 'Reclassification of financial assets,' which was issued by the IASB to amend IAS 39 and IFRS 9 in October 2008 introducing the possibility of reclassifying portfolios in unusual circumstances such as the crisis that emerged in the markets in the second half of 2008." 


\section{Model}

We present a minimal model that focuses on the rent-seeking aspects of banking supervision in a monetary union such as the Eurozone. In our model economy, national banking regulators have the power to determine whether bank loans are nonperforming, in which case the bank has to use its equity to cover the expected losses. If expected losses exceed equity, the regulator has to bail out the bank's depositors and creditors. Because the national central bank (NCB) has the power to mint Euros and lend them to domestic banks, the domestic regulator faces the following "forbearance trade-off".

If the regulator forbears a share, $\phi$, of NPLs, then this share, $\phi$, is declared performing and eligible for central bank's refinancing operations (MROs). When the NCB accepts such de facto NPLs as collateral in exchange for cash, it allows the bank to repay its creditors, who in turn can convert at-par their de facto worthless bank assets into liquid assets. The NCB ends up with assets that have a low repayment probability. The contingent losses on these de facto NPLs will be shared with the other NCBs in the Eurozone. The forbearance trade-off arises because if the domestic regulator were to reduce the forbearance rate, $\phi$, then $100 \%$ of the fiscal costs associated with the bank bailout would be borne by the country, not shared with the other countries in the Eurozone. In other words, the NCB has open access to the fiscal resources of the other countries in the monetary union, and so there is a common-pool problem. ${ }^{48}$

The above process generates an increase in the degree of evergreening, which is the share of loans granted by a bank to old debtors that have de facto NPLs. In equilibrium, evergreening is positively correlated with the NCB's domestic credit creation, and negatively correlated with the output growth gap as there is less credit available for new (profitable) projects. Furthermore, in the model, evergreening is positively correlated with Target2 liabilities to the ECB. This is because if bank creditors transfer the funds they receive to another country, the Target2 liabilities of this country go up.

\subsection{Setup}

We consider a one-good economy that lasts three periods. The economy is populated by bankers, depositors/investors, a banking regulator and a NCB.

There is a continuum of banks of measure one. Each bank is managed by a risk-neutral banker that may finance a project. A new project requires investment of one unit of the good. The following period, the project may succeed with probability $1-\eta$, or it may fail. At a given time, a banker may undertake only one project. Banks fund themselves by issuing deposits to depositors, who are risk-neutral agents with an opportunity cost $1+r$.

The banking regulator has two functions. First, it has the power to designate a loan as either nonperforming or performing regardless of whether the underlying project has succeeded or failed. This decision is key because if a loan is designated as performing, then it can be pledged as collateral at the NCB even if the project has failed. Second, the regulator provides a bailout guarantee: It pays bank creditors their promised repayment whenever a bank is unable to meet its obligations.

The timing is the following. At time 0 , each banker obtains funds from investors/depositors,

\footnotetext{
${ }^{48}$ The model does not consider the bail-in clauses that require creditors of banks to incur losses before government aid kicks in. An implicit assumption is that both taxpayers and bondholders are voters and so the government cares about both groups. Furthermore, the recent experience of Italy suggests that such bail-in clauses may not be effective.
} 
and promises an unconditional return $1+r$. They then use these funds to finance a project. In Period 1 , a time- 0 project succeeds with probability $1-\eta$, in which case it converts one unit of the good into $1+R$. With probability $\eta$, a time- 0 project fails and pays out zero. In case the project fails at time 1 , and the project is kept alive, the project may succeed in Period 2 with probability $\sigma$ and return $1+R$ at $t=2$. Meanwhile, it may fail with probability $1-\sigma$ and return zero.

At time 1, a banker with a successful time-0 project or one whose project went bust, may undertake a new project provided it can find financing. In contrast, a banker with an old failed project, may not undertake a new project.

The time- 1 payoffs are as follows. If the project is successful, the bank gets $1+R$, it pays depositors their promised repayment $1+r$ and the banker gets the remainder: $(1+R)-(1+r)=R-r$. If the project fails, the banker gets zero. Meanwhile, the regulator pays depositors their promised repayment $1+r$. The time- 2 payoffs are as follows. Payoffs for banks with new time-1 projects are the same as the payoffs at time 1. For banks that kept alive failed projects at time 1, payoffs are the following. Since no deposits were taken at time 1 , the banker gets $1+R$ if the project succeeds, while she gets zero if the project fails.

It follows that the expected profit for the representative banker that undertakes a new project is

$$
E_{t}\left(\pi_{t+1}^{\text {new }}\right)=[1-\eta][R-r], \quad t=\{0,1\} .
$$

Meanwhile, the expected profit for the representative banker that keeps alive an old, unsuccessful, project at time 1 is

$$
E_{1}\left(\pi_{2}^{\text {old }}\right)=\sigma[1+R] .
$$

We assume that a successful project's return is high enough so as to repay depositors if the project succeeds

$$
R>r .
$$

Furthermore, we assume that a new project's probability of failure is low enough so as to generate a positive net present value for the banker. Meanwhile, the net present value of unsuccessful projects is negative:

$$
\eta<1-\frac{1+r}{R-r}, \quad \sigma<\frac{1+r}{1+R} .
$$

\subsection{The Regulator's Problem}

If a bank's project fails at time 1 , the regulator needs to ensure that depositors get their promised repayment $1+r$. Since the regulator has the power to designate a project as either performing or nonperforming, this bailout can be done in two different ways. First, a bank whose project is designated by the regulator as nonperforming, must liquidate its project, and it loses all proceeds in bankruptcy procedures, so it receives a zero return. Thus, in this case, the regulator needs to pay depositors their promised repayment. Second, a bank whose project is designated by the regulator as performing - at time 1 - can pledge its assets at the NCB, up to the promised amount to depositors. Such bank commits to repay next period to the NCB this amount plus an interest rate $r$. This bank then must use the funds received from the NCB to pay depositors their promised repayment.

The regulator must balance its budget intertemporally. To finance the fiscal cost associated with the bailouts, the regulator imposes taxes on successful banks. In the first case, 
the entire cost of the bailout must be borne directly by the regulator. In the second case, the regulator does not incur any cost at time 1, but at time 2 the regulator will have to reimburse the NCB for the loses it has incurred if the bank's project fails.

The key point we wish to make is that in a monetary union like the Eurozone, the losses of an NCB may be shared with the other NCBs in the union. Thus, we assume that there are $J$ countries in the monetary union and the $\mathrm{NCB}$ of each country will incur a share $\frac{1}{J}$ of the losses incurred by the monetary union.

Recall that $\phi$ denotes the share of banks whose projects are designated by the regulator as performing, and so have the right to pledge at the NCB their old time-0 projects as collateral. In the simple setup we are considering, $\phi$ may be identified with the degree of forbearance.

The regulator chooses the forbearance rate in order to minimize the net present value of taxes. Forbearance has a convex cost for the economy, which we capture by $\frac{x}{2} \phi^{2}$. This cost is meant to capture the loss to the economy of having more nonperforming projects, as well as the higher probability that the monetary union will vote to take retaliatory actions, like curtailing the NCB's ability to accept collateral from domestic banks:

$$
\min _{\phi \in[0,1]}\left\{\tau_{1}+\frac{1}{1+r} E_{1}\left(\tau_{2}\right)+\frac{x}{2} \phi^{2}\right\} .
$$

To compute the payoff, notice that since a share $1-\eta$ of projects succeed, banks' time-1 aggregate returns are

$$
Y_{1}=[1-\eta][1+R] .
$$

Since a share $\eta$ of banks end up with failed projects, the required depositors' bailout is $\eta[1+r]$. For a given forbearance rate, $\phi$, the time- 1 fiscal cost to the regulator is

$$
\tau_{1}=[1-\phi] \eta[1+r] .
$$

At time 2 , a share $1-\eta$ of new time-1 projects will succeed, while only a share $\sigma$ of old defective projects, that were kept alive, will succeed. Since only a share $1-\phi$ of banks will start new projects at time 1 , we have that banks' time-2 expected aggregate returns are

$$
E_{1}\left(Y_{2}\right)=\{[1-\phi][1-\eta]+\phi \sigma\}\{1+R\} .
$$

Because a share $\phi$ of the failed projects were designated as performing and banks instructed to keep them alive, banks borrowed from the NCB at time 1 an amount $\phi \eta[1+r]$ and promised to repay the NCB at time $2 \phi \eta[1+r]^{2}$. Since only a share $\sigma$ of these failed projects will succeed, the expected time- 2 loss of the NCB is $[1-\sigma] \phi \eta[1+r]^{2}$. However, because the loses of the NCB are shared with the other countries of the monetary union, we have that the expected fiscal transfer that the regulator will have to make to the $\mathrm{NCB}$ is just a share $1 / J$ of the total loss:

$$
E_{1}\left(\tau_{2}\right)=\frac{1}{J}[1-\sigma] \phi \eta[1+r]^{2} .
$$

It follows that the regulator's problem can be rewritten as

$$
\min _{\phi \in[0,1]}\left\{\eta[1+r]\left([1-\phi]+\frac{1}{J}[1-\sigma] \phi\right)+\frac{x}{2} \phi^{2}\right\} .
$$


The term $\eta[1+r]$ is the bailout that has to be given to depositors at time 1 . The first term in parenthesis represent the share of the fiscal burden incurred at time 1 and the second term is the expected fiscal transfer to the NCB to cover losses due to forbearance. It follows that the optimal forbearance rate chosen by the regulator is

$$
\phi^{*}=\left(\frac{1}{J}[1-\sigma]-1\right) \frac{(1+r) \eta}{x} .
$$

The term with $\frac{1}{J}$ reflects the open access that the regulator has to the resources of the monetary union via the NCB's rediscounting window. The greater the number of countries in the union $(J)$, the lower the marginal cost to the regulator of forbearing, as it will only have to pay a share $\frac{1}{J}$ of the total cost.

If $J$ were one, the forbearance rate would not be zero because the regulator takes into account the fact that a share $\sigma$ of $\eta$-projects may be successful. If $J=1$ and $\sigma=0$, then $\phi^{*}$ would be zero.

\subsection{Evergreening}

The term evergreening refers to loans that cannot be repaid, but a bank continues to roll over such loans to avoid recognizing the loss and having to inject equity. In our model, we can identify evergreening with the loans to projects that fail at time 1 but are allowed to survive. The share of bad projects at time 1 is $\eta$, and the regulator forbears on a share $\phi$ of these nonperforming projects. Thus, in our model economy, the degree of evergreening is

$$
\Psi=\eta \phi .
$$

Replacing the optimal forbearance rate (7) in (8) we arrive at Proposition 1.

Proposition 1. In a monetary union where national central banks have the power to mint currency and to rediscount bank loans, there are incentives for banking regulators to forbear. The resulting degree of evergreening is

$$
\Psi^{*}=\left(\frac{1}{J}[1-\sigma]-1\right) \frac{(1+r) \eta^{2}}{x} .
$$

Evergreening is increasing in the share of contingent losses that can be shifted to other members of the monetary union (indexed by $J$ ) and in the degree of distress in the economy (indexed by $\eta$ ).

We can link evergreening and output growth by noting that, in our model economy, the mean growth in output between time 2 and time 1 is given by

$$
\frac{E_{1}\left(Y_{2}\right)}{Y_{1}}=1-\phi+\phi \sigma[1-\eta] .
$$

Because there is no trend growth in our model economy, we can interpret this expression as the deviation from growth trend.

Since the forbearance rate, $\phi$, equals the ratio of the degree of evergreening to the proportion of unsuccessful projects, we have

$$
\frac{E_{1}\left(Y_{2}\right)}{Y_{1}}=1-\Psi\left[\frac{1-\sigma[1-\eta]}{\eta}\right] .
$$

That is, greater evergreening, leads to a larger negative gap of output growth from its trend. 


\subsection{Price of Securities}

Consider an equity-like security that confers the right to the time-2 profits of a bank that starts a fresh project at time $1-$ call it an N-security. Since agents are risk-neutral, the time- 1 price of this $\mathrm{N}$-security is

$$
P_{1}^{\text {new }}=\frac{[1-\eta][R-r]}{1+r} .
$$

Similarly, the time-1 price of a security (call it an O-security) that confers the right to the time-2 profits of a bank that keeps alive an unsuccessful project at time 1 is

$$
P_{1}^{\text {old }}=\frac{\sigma[1+R]}{1+r} .
$$

Clearly, $P_{1}^{\text {old }}<P_{1}^{\text {new }}$ because old projects have a negative net present value, by (2). Consider now a hybrid security that combines N-securities and O-securities, in proportions $1-\phi$ and $\phi$, respectively. The price of such hybrid security is

$$
P_{1}^{\text {hybrid }}=[1-\phi] \frac{[1-\eta][R-r]}{1+r}+\phi \frac{\sigma[1+R]}{1+r} .
$$

One could bring the simple formulas in (11) and (12) to the data and determine the implied forbearance rate or the degree of evergreening.

\subsection{The National Central Bank}

As we have seen, the balance sheet of the NCB is the vehicle via which the banking regulator may transfer to the Eurozone the future contingent costs of regulatory forbearance. This is because potentially bad bank loans are pledged as collateral to the NCB via the monetary rediscounting operations. By virtue of being part of the Eurosystem of central banks, each $\mathrm{NCB}$ can mint fresh Euros in exchange for the collateral it receives. Because any losses on the collateral will be shared with the Eurosystem, we say that the NCB has "open access" to the resources of other countries in the Eurozone. ${ }^{48}$

As in standard models, the assets of the $\mathrm{NCB}$ are domestic credit to banks $(D)$ and international reserves $(I R)$, while the liabilities of the $\mathrm{NCB}$ are the currency it prints plus the excess reserves of the banking system deposited at the $\mathrm{NCB}(E R)$. In the Eurozone, we should also include the NCB's so-called Target2 claims and liabilities with the ECB:

$$
D+I R=M+E R+T g 2 .
$$

Domestic credit to banks is the sum over all loans (MROs) to banks - discussed above-plus the initial domestic credit:

$$
D=D_{0}[1+r]+\int \gamma_{i} d_{i} .
$$

We will assume that $I R, M$, and $E R$ are constant, and so the NCB budget constraint is

$$
\Delta D=\Delta T g 2 .
$$

\footnotetext{
${ }^{48}$ Note that part of the credit claims are accepted by explicit loss sharing, while others are de jure without loss sharing. The two exceptions from the loss-sharing rule are (i) items accepted under the national eligibility criteria, following the ECB Council's decision on December 8th, 2011, and (ii) emergency liquidity assistance (ELA). In Section 2, we discuss these two exceptions and argue that de facto, there is risk sharing here as well.
} 
In our simple economy, the change in the NCB's domestic credit at time 1 is $\phi \eta[1+r]$, where $\phi$ is the share of failed projects $\eta$ that are designated as performing, so that banks could borrow $\phi \eta[1+r]$ from the NCB.

Combining this equation with the evergreening index (8), we arrive at Proposition 2.

Proposition 2. In our model economy, the degree of evergreening is equal to the increase in the NCB's domestic credit

$$
\Delta D=\Delta T g 2=\Psi
$$

We would like to note that in a more complicated setup, the increase in NCB domestic credit in the model economy would include other elements in addition to evergreening. Such an economy would be populated by several power holders with the power to appropriate fiscal resources and thus have open access to the NCB's rediscounting window. Power holders relevant in the Eurozone context are the banking regulator, the fiscal authorities, and provincial governments. The fiscal authorities may be a group of agents, whose decisions determine the fiscal deficit, which has to be financed by issuing government debt, which is then purchased by banks. Banks in turn would pledge as collateral these government bonds to the NCB. Similarly, provincial governments in many countries can issue debt, which is then purchased by banks that in turn pledge them at the NCB (Spain today is a prime example; Brazil and Argentina in the 1970s and 1980s suffered this problem; Mexico, starting in year 2000). 


\section{$4 \quad$ Empirical Implications of the Model}

In this section, we investigate the model's empirical implications. Namely, in a monetary union with a common pool problem such as the Euro Area, if the banking system is in distress, then banking regulators have incentives to forbear and declare that some NPLs are performing. In this way, the potential cost of bank failure can be shifted to the Euro Area via the Euro system of central banks. The result of this forbearance is that instead of writing off the bad loans, banks extend them over and over again, and so can make fewer new loans.

Here we test the null hypothesis that countries in the Euro Area are more likely to exhibit evergreening than other countries. Furthermore, within the Euro Area, our hypothesis is that countries with poorly capitalized banking systems are more likely to exhibit evergreening than other countries.

The challenge of this empirical exercise is that there exists no off-the-shelf evergreening data. To obtain a proxy for the changes in evergreening, we designed a set of questions to be added to the quarterly World Economic Survey (WES) of the Munich-based ifo Institute for Economic Research. The questionnaire was sent to more than 1,000 experts in 80 countries in January $2017 .{ }^{50}$

A unique feature of this dataset is the very well-informed group of participants. Currently, $31.33 \%$ of the panelists work in high-level positions for international corporations (9.86\% financial, $21.47 \%$ nonfinancial); $34.82 \%$ in universities, research institutes, and think tanks; $12.83 \%$ in national ministries or agencies; $7.59 \%$ in associations or chambers; $3.93 \%$ in embassies and consulates; $2.97 \%$ in central banks; $2.36 \%$ in multilateral organizations (such as OECD and IMF); and the remaining $4.19 \%$ in medium or small enterprises. ${ }^{51} \mathrm{We}$ ask the experts four questions:

(i) Since 2008, how has the share of nonperforming loans changed in your country?

(ii) Since 2008, how have banks' attitudes to approving a new business loan changed?

(iii) Since 2008, how have banks' attitudes to rolling over or extending the maturity on existing loans changed?

(iv) Since 2012, how has the supervision of banks changed the ability to roll nonperforming loans over?

50 While the data is not available online, it is possible to access it in Munich, where we also produced our descriptive statistics and the regression results.

51 More information about the dataset can be found on the ifo website (doi: 10.7805/ebdc-wes-2014). 


\subsection{Nonperforming Loans}

The first question on our survey addresses the NPL problem in each country. This generates a proxy for the true underlying state of the banking system. Unlike evergreening, NPLs do have an official recording and we can compare the survey participants' assessment to each country's official NPL record. ${ }^{52}$

Panel A of Figure 3 shows that officially recognized NPLs have been increasing considerably in the Euro Area. In Greece, Italy, Portugal and Spain (GIPS), on average $18.4 \%$ of loans were nonperforming in 2016 , compared to only $5 \%$ in 2008 . This is a very large increase compared to the Euro Area average, which currently stands at $5.4 \%$ (up from $2.5 \%$ in 2008), and in particular when compared to more stable countries within the Euro Area, like Germany, the Netherlands, Finland, and Luxembourg (DNFL), with 2.5\% (up from $1.7 \%$ in 2008). But even in DNFL, NPLs are high when compared to those in the United States, where nonperforming loans have been falling since 2009 and currently make up only $1.5 \%$ of total gross loans.

Panel B of Figure 3 displays a similar pattern in the survey data. It shows the percentage of survey participants noticing an increase in the level of NPLs since 2008 in their country. A large share $(70.2 \%)$ of the GIPS respondents confirms the increase in NPLs. This figure is considerably larger than in the rest of the world (41.5\%), as well as in DNFL (21.7\%), and it is far above the value in the United States $(8.7 \%)$.

Note that the survey participants do not observe NPLs directly. They only receive a noisy signal of true underlying levels non-performing loans. Nevertheless, the dynamics of NPLs in both the survey and the official data are quite similar, thus validating the expertise of our survey-respondents.

The GIPS are countries that are running low on capital and some banks, as documented in Section 2, have required multiple recapitalizations. That is, the high share of NPLs is correlated with a poor capital base. Thus, regulators are facing the trade-off that forms the core of the theoretical model: Forbearing allows a bank with high NPLs and low capital to survive the next stress test.

52 The survey participants, unlike regulators, however, are not subject to the political pressure and institutional incentives for underreporting documented in the institutional section. 
Figure 3: Nonperforming loans

A) NPLs - official data [\% of gross loans]

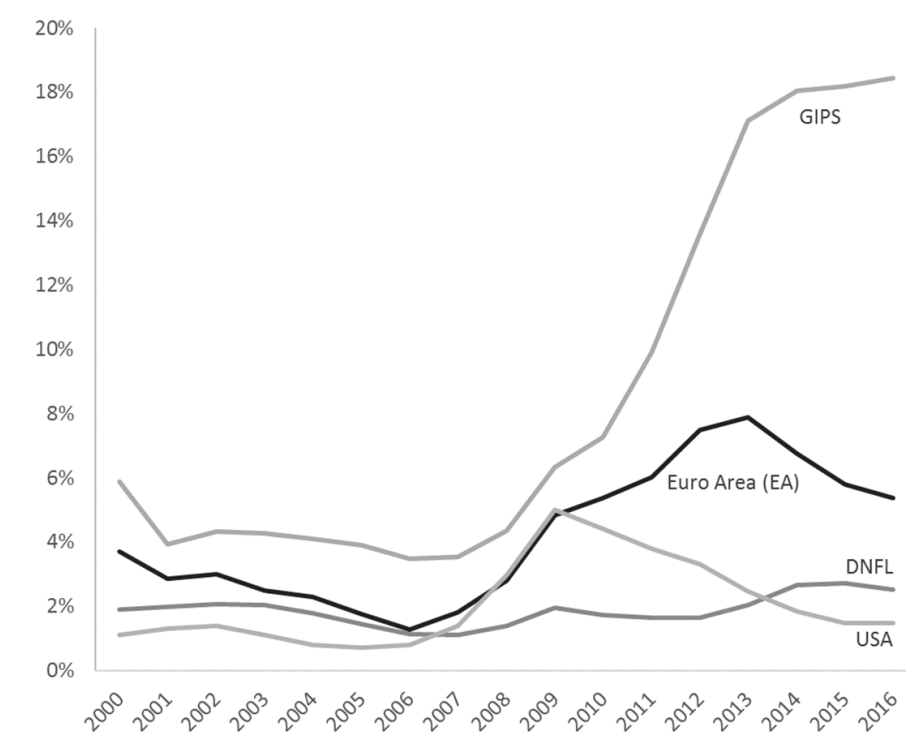

B) NPLs - survey data [\% respondents noticing an increase in NPLs]

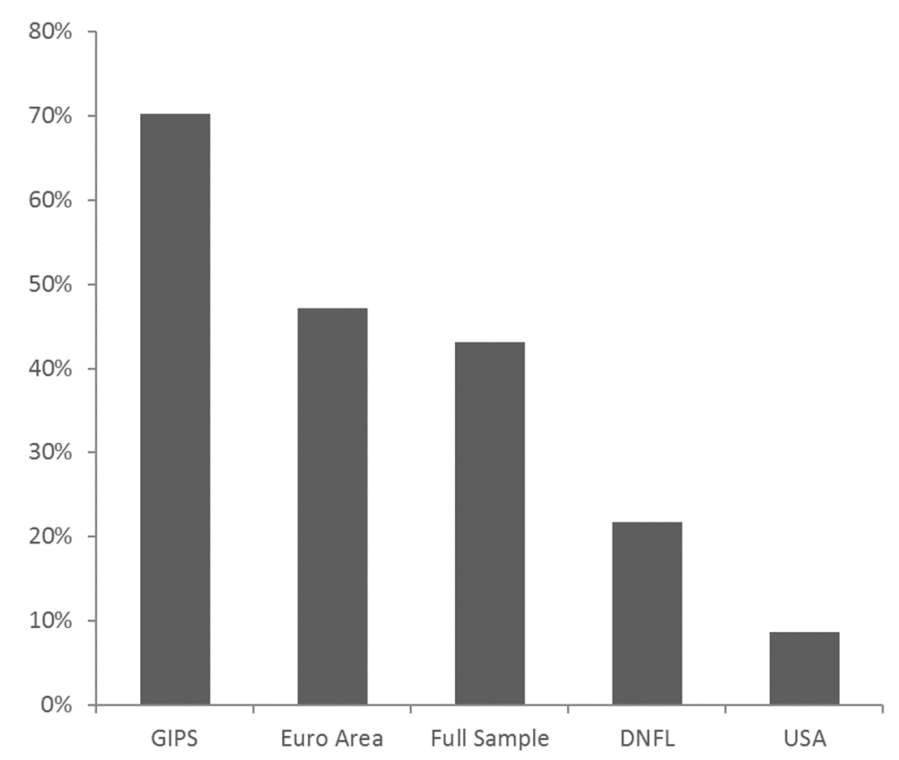

Sources: World Bank WDI (FB.AST.NPER.ZS), World Economic Survey 01/2017. 


\subsection{Proxies for Evergreening}

We construct an EG index using Questions 2 and 3, regarding the banks' credit policies. If banks and regulators indeed adhere to an evergreening strategy, it should have become relatively easier to roll an existing (potentially nonperforming) loan over than to receive a new one. We therefore take the differences in the answers to these two questions as our evergreening proxy.

Figure 4 shows that there are notable differences between different subgroups of countries. In the Euro Area, we see a larger increase $(25.5 \%)$ than in the rest of the world $(19.2 \%) .{ }^{53}$ This difference is particularly striking when comparing the Euro Area to the United States (13.9\%). We also observe an asymmetry within the Euro Area: The phenomenon of evergreening is more pronounced in Greece, Italy, Portugal and Spain $(28.6 \%)$ than in Germany, Netherlands, Finland and Luxembourg (20.5\%). The clearest difference is observable when using our banking-distress index, generated from Question 1 of the survey. Experts within the Euro Area observing high banking distress, also observe the largest increase in evergreening $(31.7 \%)$.

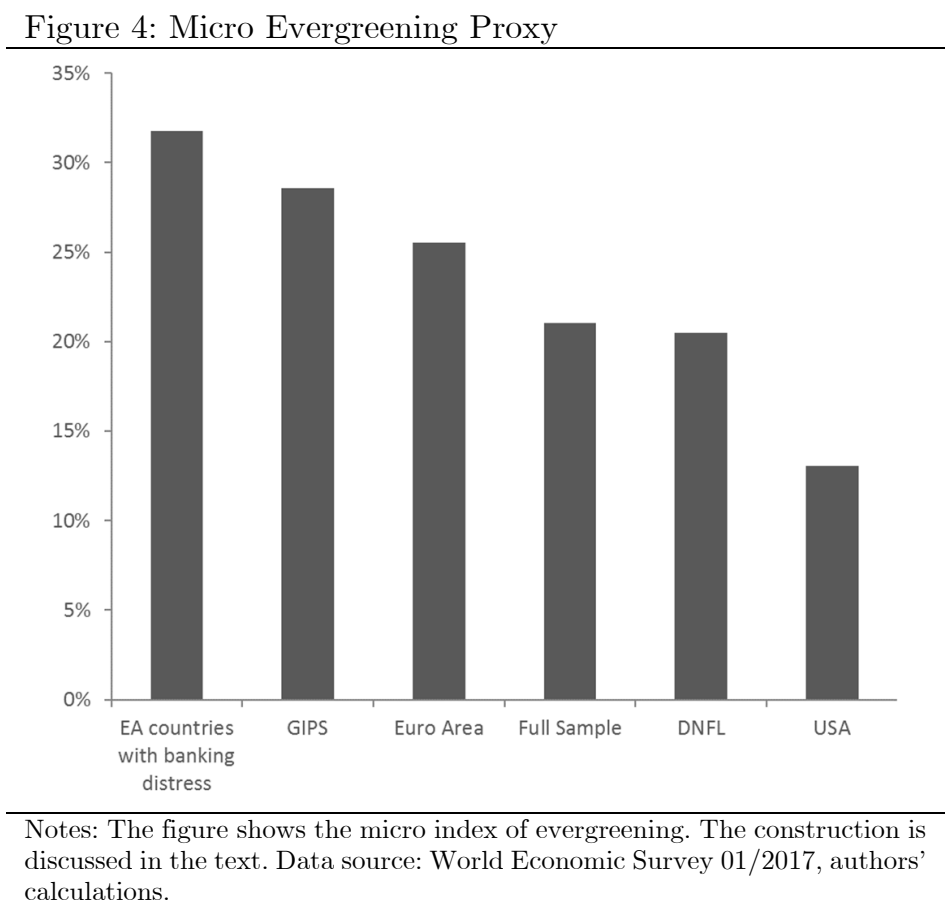

53 We assume that each expert receives a noisy signal of the evergreening change, with different pre-visions. A greater evergreening increase suggests a higher mean of the noisy signal, making the expert more likely to give responses to the credit questions that imply evergreening. 
To validate our survey-based EG index, we construct a second proxy, based on bankbalance-sheet data from the ECB. The idea is to compare the data on new loans with the changes in total loans. This is feasible because, in 2003, the member countries of the Eurosystem established a new common database on new loans to enterprises. ${ }^{54}$

As illustrated in Panel A of Figure 5, this data shows that new lending in the Euro Area has dried up since the onset of the crisis. Remarkably, however, total outstanding loans has not fallen substantially. This suggests that some of the existing loans must have been extended or rolled over. The gap between the two series, the change in total loans minus new loans, is therefore our evergreening proxy.

Figure 5: New Lending and Evergreening in the Euro Area

A)

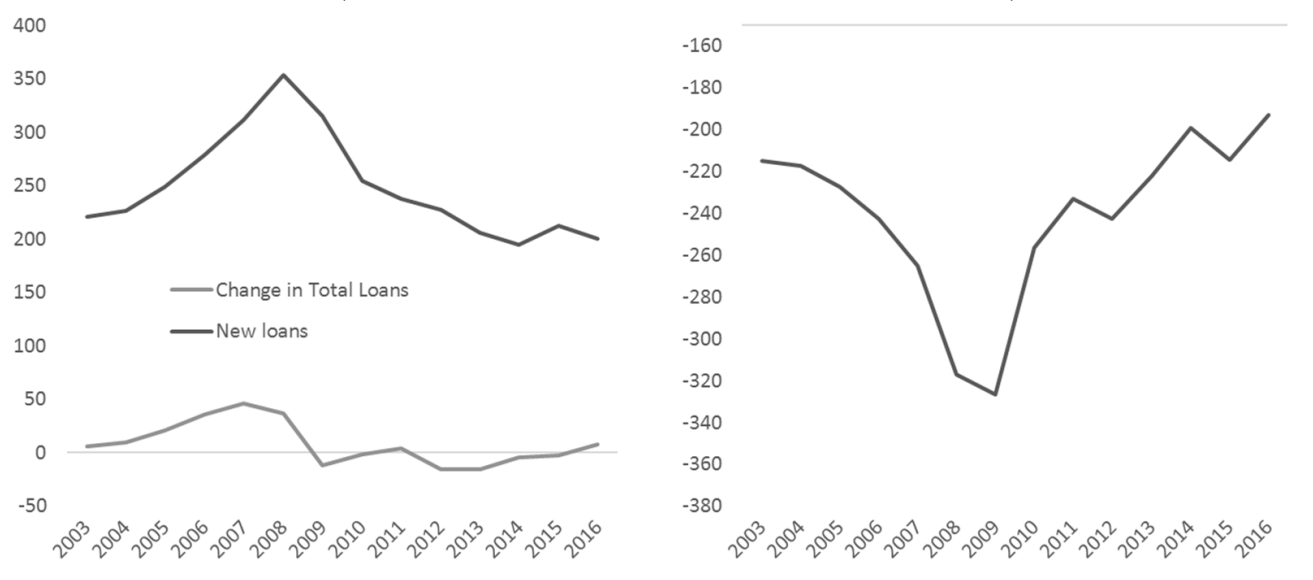

Notes: The light grey line in Panel A shows the change in total loans $(D(T L))$ of the banking sector [M€]. The darker grey line shows the banks' new business loans $(N L),[\mathrm{M} €]$. Panel B shows our macro evergreening proxy (i.e., $E G=D(T L)-N L$, in M). Data sources: Statistical Data Warehouse of the ECB (BSI.Mfi.N.A.A20.A.1. U2.2240.Z01.E; MIR.Mfi.B.A2A.A.B.0.2240.EUR.N; MIR.Mfi.B.A2A.A.B.1.2240.EUR.N), authors' calculations.

The trend reversal that occurred around 2008/9 is certainly striking. Prior to the crisis, new loans were increasing more rapidly than the change in total loans; since the crisis, this relationship has been reversed. Our evergreening proxy, depicted in Panel B of Figure 5, displays a clear trend-break, which interestingly coincides with the beginning of the ECB's full-allotment policy.

54 When this dataset was established in 2003, it included about 1.800 institutions, more than $80 \%$ of the total business volume (see the ECB's inaugural press release, 10 December 2003, and the accompanying presentation by Steven Keuning, Director General, Statistics). It is important to note that the two concepts, "new loans" and "total loans," are not from a common database. The total loans are a comprehensive statistical recording, while new loans are an estimate based on a sample of banks. 
Figure 6: Evergreening-Differences within the Euro Area

A) Bank lending in crisis countries

B) Bank lending in noncrisis countries

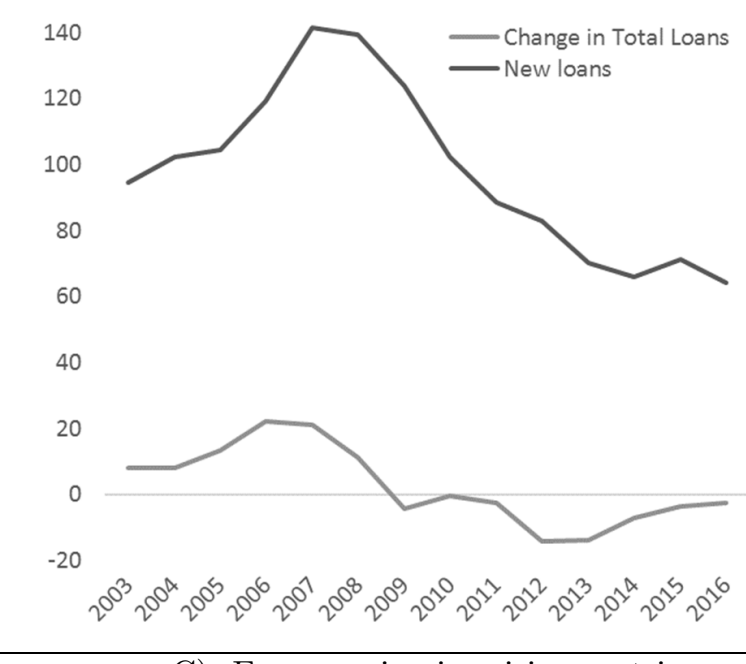

140

100

80

0

C) Evergreening in crisis countries

$-60$

$-70$

$-80$

$-90$

$-100$

$-110$

$-120$

$-130$

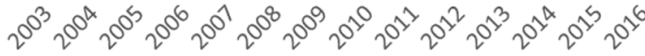

D) Evergreening in noncrisis countries

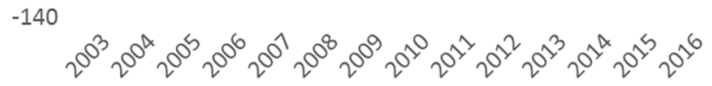

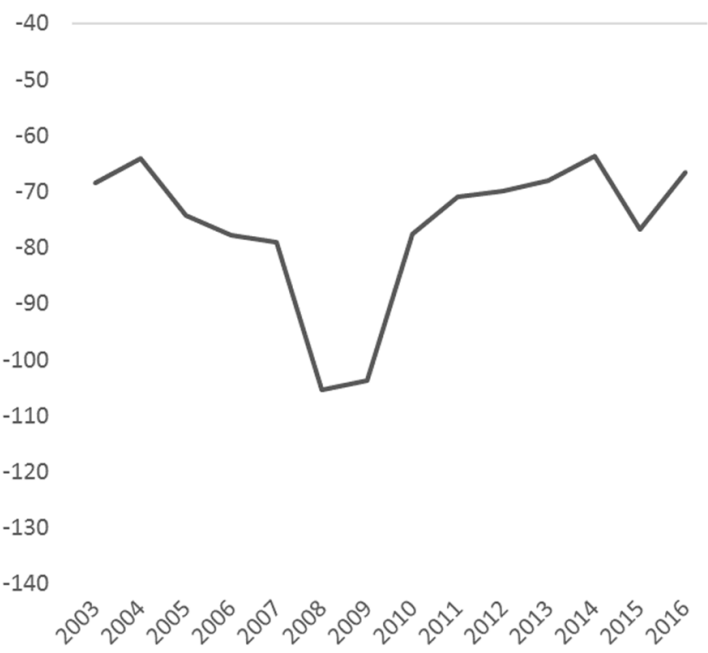

Notes: Panel A shows banks' new loans $(N L)$ and the change in total loans $(D(T L))$ for the crisis countries (Italy, Portugal, and Spain). Panel B shows the same for Germany, Finland, and the Netherlands. Panel C depicts our macro index of evergreening $(E G=D(T L)-N L)$ for Italy, Portugal and Spain. Panel D shows the same index for Germany, Finland, and the Netherlands. Data are unavailable for Greece and Luxembourg. All data in ME. Data sources: Statistical Data Warehouse of the ECB (BSI.Mfi.N.A.A20.A.1.U2.2240.Z01.E; MIR.Mfi.B.A2A.A.B.0.2240.EUR.N; MIR.Mfi.B.A2A.A.B.1.22 40.EUR.N), authors' calculations. 
We now compare subgroups of countries in the Euro Area to see where evergreening has been increasing most strongly since the beginning of the financial crisis in 2008. Our survey-based index showed that in the GIPS there was a stronger increase in evergreening than in the rest of the Euro Area.

Panels A and B of Figure 6 document that a similar pattern is also observable in the balance sheet data: New lending has declined in both crisis and noncrisis countries in the Euro Area, but the decline in the crisis countries is considerably more pronounced. Panels $\mathrm{C}$ and D of Figure 6 show that the gap between new loans and the change in total loans has also increased more rapidly in the crisis countries since 2008. Furthermore, it continuously increased up to 2016 (with only a small correction in 2011-2012), while in noncrisis countries, most of the adjustment was complete by 2010 .

A shortcoming of this index is that we can only construct it for Euro Area countries, not for the rest of the world. The new-loan data set is comparable only within the Euro Area and has been recorded only since 2003. At the country level, the data are quite incomplete and unbalanced. Nevertheless, the index is helpful to do the validation exercise of our survey-based proxy, as rigorously as possible.

\section{Regression analysis}

To test whether the differences between subgroups of countries that we observed in Figure 4 are statistically significant, after controlling for other factors, we analyze the survey data in a cross-section multivariate probit regression. The full empirical specification of our model is given by

$$
E G_{i}=\alpha+\lambda_{1} E A_{i}+\lambda_{2} B D_{i}+\lambda_{3}\left(E A_{i} \times B D_{i}\right)+\beta_{1} C_{i}+\beta_{2} X_{i}+\varepsilon_{i},
$$

where $E G_{i}$ takes the value 1 if a respondent, $i$, believes the banks' attitudes towards giving new business loans has become more restrictive since 2008 than their attitudes towards rolling over existing loans, ${ }^{55} E A_{i}$ is a dummy variable capturing membership in the Euro Area; Banking Distress $\left(B D_{i}\right)$ captures whether the respondent perceived an increase in NPLs in her country since 2008; $C_{i}$ is a vector of control variables including the short-term interest rate, banking-sector-specific credit constraints, present economic situation and perceived capital shortages ${ }^{56}$ and the vector $X_{i}$ contains a set of extended control variables capturing the respondents' evaluation of different potential obstacles for lending growth in their country (including government policy, competitiveness, inflation, foreign debt, etc.). These control variables also come from the WES survey and are regularly asked of all participants.

In our model economy, forbearance and evergreening arise in economies that have open access to the fiscal resources of other countries in a monetary union. Furthermore, the degree of evergreening depends on both the true share of underlying unsuccessful projects in the economy - which in turn determines the capital base of the banking system - and the rate of forbearance chosen by the regulator. In our regression, the Euro Area dummy variable $(E A)$ proxies for the existence of open access at the ECB and the $B D$ dummy variable is a proxy for banking distress and the true share of bad projects in the economy.

55 Technically, the probit model links our binary variable $E G_{i}$ to an unobserved continuous variable $E G_{i}^{*}$ by an index function $E G_{i}=1\left[E G_{i}^{*}>c\right]$. In order to standardize the threshold value to be zero, $c=0$, we include a constant in equation (10). Furthermore, the error term is assumed to follow a standard normal distribution, $\varepsilon_{i} \sim N(0,1)$. The parameters are then estimated using Maximum-Likelihood.

56 See, for instance, Louzis et al. (2012) and references therein. 
The model predicts a positive correlation between evergreening and the EA dummy, and a positive correlation between evergreening and banking distress interacted with the EA dummy, even when controlling for other factors, such as the interest rate. As we can see in Table 2, both hypotheses are not rejected in the regressions. Respondents from the Euro Area are $6.3 \%$ percentage points (pp) more likely to recognize an increase in evergreening compared to non-Euro Area respondents (Column 1) and experts in countries with high banking distress are also more likely to report evergreening (Column 2). These differences are statistically significant at the $5 \%$ and $10 \%$ level, respectively. Looking at the interaction between our BD and EA dummy variables, we also find a statistically significant difference between BD countries in the Euro Area and BD countries in the rest of the world (Column 3). This difference is economically important. Respondents from BD countries in the Euro Area are 17.0pp more likely to report evergreening than respondents from the rest of the world. Interestingly, when using the $5 \%$ significance criterion, the same regression shows that Euro Area countries without banking distress do not differ significantly from the rest of the world.

In Columns 4-6, we add several other control variables. The interaction between high $\mathrm{BD}$ and EA, however, remains statistically significant in all the regressions. In Column 4, we include bank-specific credit constraints, evaluations about the countries' present economic situation, expected changes in the short-term interest rate, and the severity of capital shortages. In Column 5, we further add expected long-term interest rates, and assessments of the severity of different factors for the respondent's country: competitiveness, government policies in general, insufficient demand, and inflation. Including all variables at once, none of these controls seems to be of great importance in explaining evergreening.

As a robustness check and in the absence of clear theoretical predictions about some of the control variables, we estimate equation (10) following a stepwise-regression strategy. The interaction term capturing respondents of high-BD Euro Area countries remains positive and statistically significant at the $1 \%$ level, albeit with a slightly lower coefficient: Being a respondent of this group increases the probability of acknowledging evergreening by $16.7 \mathrm{pp}$. Another important determinant of evergreening seems to be the short-term interest rate. It may be more attractive for banks to roll old loans over than to give new ones when a decrease of the interest rate can be foreseen. The coefficient of short-term interest expectations is consistent with this reasoning. Respondents expecting a decrease in interest rates, have a $4.2 \mathrm{pp}$ higher probability of experiencing evergreening. Lastly, respondents seeing government policy as a less important obstacle for doing business in their country are also less likely to observe evergreening (3.5pp).

In sum, evergreening in the Euro Area, in particular in countries with high banking distress, cannot fully be explained by standard variables such as the present economic situation, expected interest rate changes, or country-specific credit constraints. Our results are thus consistent with evergreening being a rather distinct problem of the Euro Area. The unobserved degree of regulatory forbearance appears to be a plausible explanation for this empirical finding. 
Table 2: Determinants of Evergreening in Survey Data

Dependent variable: Micro-level evergreening index

\begin{tabular}{ll}
\hline Variables & $(1)$ \\
\hline EA & $0.063^{* *}$
\end{tabular}

$\mathrm{BD}$

(2.09)

(2)

(3)

$(1.85)$
0.114

$0.114^{* * *}$
$(4.16)$

$\mathrm{EA} \times \mathrm{BD}$

(full effect)

Standard controls:

Credit constraints

Present economic situation

Short-term interest rates

Perceived capital shortage

$0.056^{*} \quad 0.074^{* *}$

0.069

$(1.56)$

$0.114^{* * *}$

$0.082^{* *}$

$(4.16)$

$(2.51)$

$0.170^{* * *}$

$0.163^{* * *}$

$0.096^{* * *}$

$(2.67)$

$0.183^{* * *}$

(8.13)

Stepwise-

regression

$(9.27)$

$-0.011$

$\begin{array}{ll}-0.008 & -0.011 \\ (0.29) & (0.38)\end{array}$

$0.040 \quad 0.040$

$(1.63)$

0.040

$(1.63)-(1.30)$

$\begin{array}{ll}0.039 & 0.049 \\ (1.56) & (1.45)\end{array}$

$0.042^{*}$

$0.003-0.0150$

$(0.13) \quad(0.56)$

Extended controls:

Problem: Competitiveness

0.007

$(0.28)$

Long- term interest rates

$-0.113$

(1.09)

$-0.035--0.035^{*}$

Problem: Government policy

(1.46)

(1.73)

Problem: Insufficient demand

$-0.017$

$(1.88)$
$0.094^{* * *}$

$(3.06)$

(10.91)

Problem: Inflation

$(0.67)$

0.008

(0.29)

$\begin{array}{llllll}\text { Further controls (foreign debt, } & \text { No } & \text { No } & \text { No } & \text { No } & \text { Yes }\end{array}$

deficits, corruption, trade

policy, expected growth, from

WES survey)

Observations 20

$939 \quad 939 \quad 939$

Notes: Estimated values are marginal effects at the variables' means except for dummy variables, where the change in the predicted probability for a discrete change from zero to one is reported. Absolute Z-statistics in parentheses. Statistical significance is indicated by ${ }^{*} p<0.1,{ }^{* *} p<0.05$, and ${ }^{* * *} p<0.01$. Data sources and variable construction: see Section 8.3 of the data appendix. 


\subsection{The Impact of Reforms}

Finally, we asked the survey participants whether they think that supervision has changed the ability to roll NPLs over in their country. Their responses are summarized in Figure 7 below. While there seems to be some effect of recent changes in banking supervision, roughly $40 \%$ of respondents in the Euro Area believe those changes have not prevented evergreening (or even facilitated it). Again, we observe differences across countries. The share of experts who believe the supervision reforms were ineffective was smallest in the GIPS. Also in DNFL, the share was smaller than in the rest of the world.

Figure 7: Were Supervisory Reforms Effective?

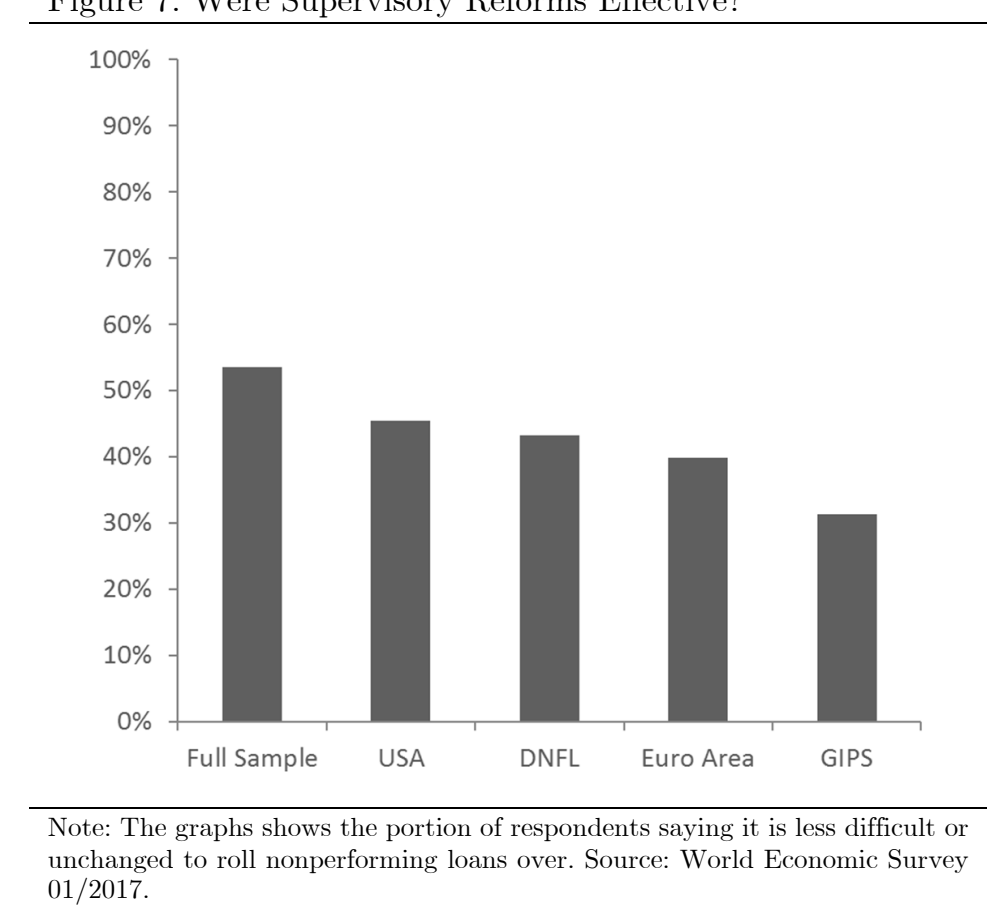

\subsection{Literature Review}

The most well-known example of evergreening comes from Japan. It is often argued that it played a major role in explaining the Japanese economic slowdown after the early 1990s' asset-price collapse. This is demonstrated in an early contribution by Caballero et al. (2008), which used the term "zombie lending." In a creative destruction model, they show how zombie lending keeps unproductive firms alive, creates credit constraints on healthy firms and, thus, slows economic growth. The results are empirically validated in industrylevel dataset explaining sectoral productivity, investment, and unemployment. For an application of their approach to the Euro Area see Acharya et al. (2016). 
While Caballero et al. (2008) focus on evergreening's macro implications, we aim to construct a direct proxy of evergreening during the Euro crisis. Caballero et al. (2008) measure evergreening using implicit interest rate subsidies to unproductive firms. We define evergreening as the degree to which banks roll existing loans over rather than giving out fresh ones. To our knowledge this is the first attempt to create a direct proxy of evergreening for a large set (80) of countries.

Sinn (2003) models externalities among regulators with regard to capital requirements. He argues that the same reasons for regulating the banking system in the first place arise again when regulators compete with each other. In a domestic economy, banks have an incentive to hold too little capital because of the asymmetric information on the quality of their assets. Regulators, in turn, have an incentive to regulate the domestic banking system too little, when competing with other regulators. While the two models have in common that national regulators can generate negative externalities for others, they differ in the sense that neither the institutional aspects of the currency union, the link to money creation, nor the political economy aspects are included in Sinn's model.

Externalities in currency unions have also been modeled by Aizenman (1992), who focuses on the distribution of seigniorage, with special reference to the former Yugoslavia. In Yugoslavia, regional branches of the central banking system could divert seigniorage profits for their region. Aizenman models the inefficiency of this institutional setting, which has similarities to the European setting. Unlike Sinn (2003), Aizenman (1992) actually models the competition among decision makers within a monetary union and the associated losses in welfare. Compared to our model, he does not consider the link to regulatory forbearance and the specific institutional aspects of the Euro Area.

Casella (1992) argues that small open economies would not join a monetary union unless there was an asymmetric distribution of power. The small countries in her model anticipate a disproportional influence, compared to their size, which helps to transfer seigniorage revenues in their favor. This effect is present in the institutional arrangements of the Euro Area and it is implicitly present in our model where any countries can use regulatory forbearance to shift costs to the ECB.

In Alesina and Drazen (1991), distortionary taxation creates a bias to not balance the budget and place the burden on others. The cost of bank resolution in our model can be interpreted abstractly to have a similar role as the distortionary taxation in their model. Policymakers try to avoid this cost by delaying stabilizations, generating an inefficient solution compared to a unitary decision maker.

Finally, some papers have theoretically modeled the impact of voting power on longterm inflation, starting from a Barro-Gordon-type setting on inflation bias. An early paper that pointed out that regional interests may lead to inefficient monetary policies, by analyzing the voting power of the ECB council, was von Hagen and Süppel (1994). Dinger et al (2014) take their model as a motivation to illustrate the inflation bias in the Euro Area arising from the fact that the long-term consequences of inflation - in an integrated economy - will be spread across countries.

This analysis is not limited to Europe; the US Federal Reserve system has been analyzed in a similar context (see Friedman and Schwartz, 1963; Eichengreen, 1990). The authors analyzed the great depression in the early 1930s and found that the regional Federal Reserve branches had the ability to pursue regional policies, prolonging the great depression. It is argued in their papers that the introduction of the Federal Open Market Committee in 1935 was important to shifting the power back to the center. Bordo and Schwarz (1999) provide an overview of monetary policy regimes and their economic performance in economic history. 


\section{Other Implications of Open Access to the Common Pool}

The model predicts that within a monetary union, after an adverse external shock, countries facing a forbearance trade-off should experience a larger increase in refinancing credit and should have larger Target2 deficits. As we document below, these patterns are exhibited in the Euro Area, a group of countries that all experienced an adverse external shock to their banking systems, have a common monetary policy, but differ in their degree of banking distress due to different initial capital bases.

Panel A of Figure 8 illustrates the evolution of MROs since the introduction of the monetary union. They have been increasing since the introduction of the full-allotment policy. And as collateral requirements were reduced and NCBs decided to accept additional credit claims in 2011, they have been exploding. After 2012, MROs initially reverted to a declining path. But more recently, following the financial turmoil in Greece 2014/15 and more recently in Italy 2016/17, they have been increasing again. In 2015, Greek banks had borrowed $€ 90$ bn - about half of GDP - from its central bank. In 2016/17, Italian banks have borrowed more than $€ 100$ bn, $5.9 \%$ of GDP, and Spanish banks had borrowed more than $€ 40$ bn, $3.5 \%$ of GDP. At the time of this writing, MROs in both Italy and Spain are again on an explosive path.

Panel $\mathrm{C}$ of Figure 8 shows that shortly after MROs started to decline, the ECB initiated its expanded asset-purchase program, also known as QE. Thus, at the same time that banks were repaying their central-bank loans, the ECB purchased assets from them, which in part gave banks the liquidity that was needed to repay the LTROs to the NCBs, without touching the NPLs and evergreened loans on their balance sheets. In the last two years, the QE program has been the strongest driver of the total expansion of the ECB balance sheet. As Panel B shows, MROs and QE purchases taken together display an increase of about $€ 1$ trillion since the introduction of the monetary union-about $10 \%$ of GDP in the Euro Area's member countries.

Confirming the prediction of our model, the cumulative Target2 balances, ${ }^{57}$ displayed in Panel D, were highly correlated with the total monetary expansion (MROs plus QE purchases). The total value of the Target2 liabilities of the GIIPS has also increased by about $€ 1$ trillion and displays a nearly identical time path. The correlation between the two time series is 0.978 . Thus, nearly none of the monetary expansion during the crisis was directed to finance domestic investment. Instead it was used for either financing current account deficits, repayments of international loans, or outright capital flight within the Euro Area.

${ }^{57}$ See Sinn and Wollmershäuser (2012) for this interpretation. 
A) Central bank claims on MFIs (excl. ELA)

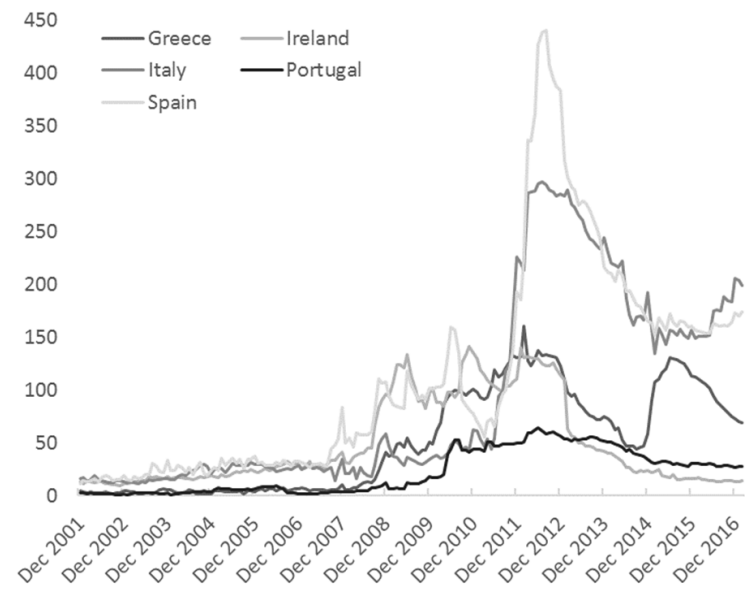

C) Central bank claims on General Government (bond purchases)

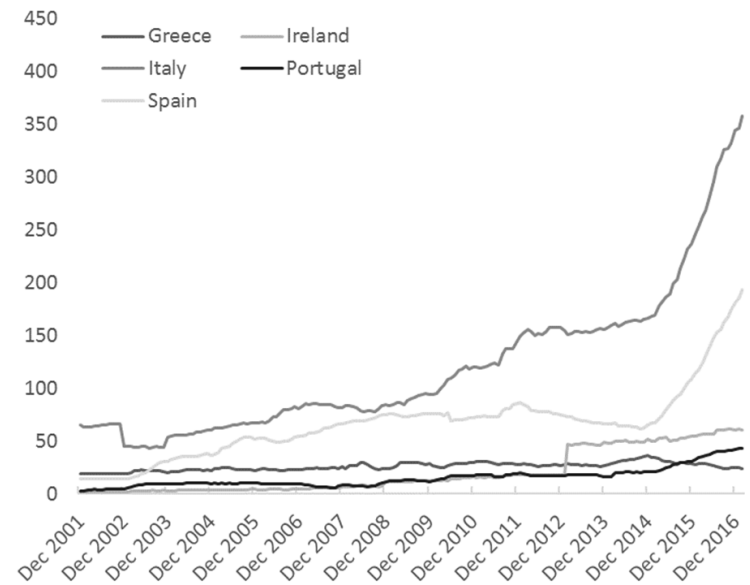

B) Total monetary expansion (GIIPS)

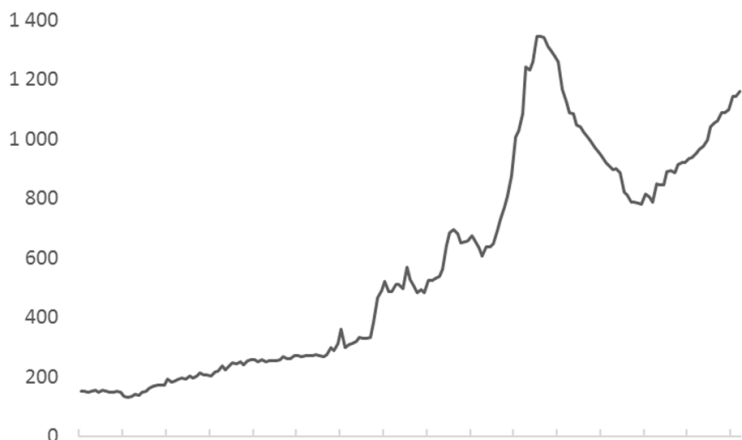

$-200$

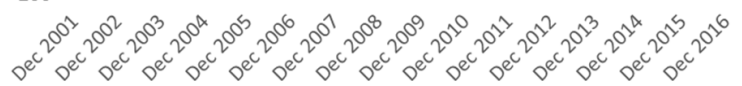

D) Target2-Balances (GIIPS)

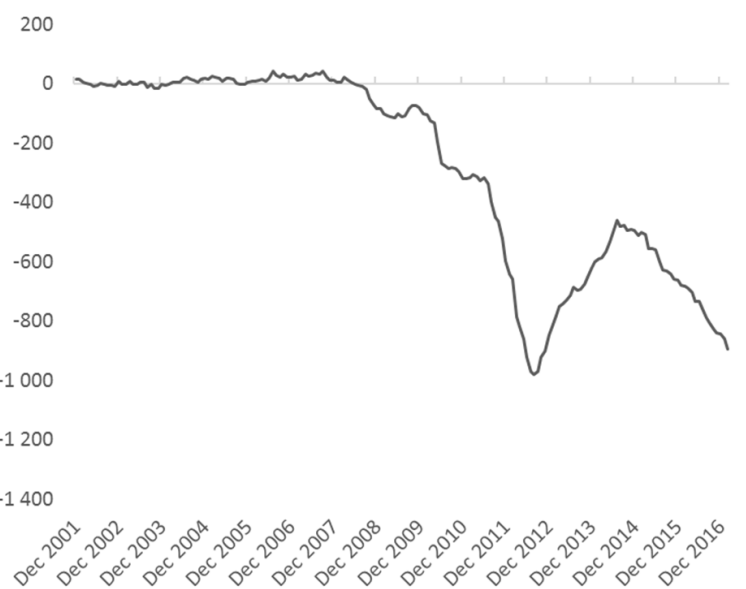

Notes: Total discretionary expansion is the sum of central bank's claims on MFIs and general governments of the crisis countries. Data source: ECB Statistical Data Warehouse (Codes: BSI.Mfi.N.N.A20.A.1.U2.1000. Z01.E; BSI.Mfi.N.N.A30.A.1.U2.2100.Z01.E; TGB.Mfi.N.A094T.U2.EUR.A), authors' calculations. 


\section{Conclusions}

After the 2008 crisis, it became evident that there was a common-pool problem in the Euro Area. Because an NCB could accept potential NPLs as collateral from domestic banks in exchange for freshly minted Euros, an NCB could transfer the potential losses into the balance sheet of the ECB. To eliminate this virtual open access to the fiscal resources of the entire monetary union, the ECB introduced the SSM in 2013.

Our analysis shows that although the SSM has made great progress in eliminating the common pool, open-access loopholes still remain.

We present a model where regulatory forbearance allows national regulators to tap into the common pool of Euro Area fiscal resources. When the banking system is in distress, regulators have incentives to forbear and declare bad loans as officially performing. In this way, banks may roll the bad loans over (i.e., evergreen them) and pledge them as collateral at the NCB.

We bring the model to the data by constructing a new evergreening index based on a questionnaire administered by the ifo Institute for Economic Research in January 2017. Regressions using this index indicate that evergreening is more acute in the Eurozone than in other countries. Furthermore, within the Eurozone, evergreening is larger where banks are in greater distress. These differences are statistically significant when controlling for other influences, such as inflation, interest rate, and business-cycle expectations. At the macro level, we find that evergreening is positively correlated with NCB credit to banks and with Target2 liabilities to the ECB.

Our finding suggests that NCB monetary expansion by itself may not be sufficient to induce more investment and growth in the Euro Area. Reducing the degree of NPL evergreening may allow banks to issue more fresh loans to new profitable projects and in this way reignite economic growth. 


\section{$7 \quad$ References}

Acharya, V. V., Eisert, T., Eufinger, C., and Hirsch, C. W. (2017). "Whatever it takes: The real effects of unconventional monetary policy." NYU Stern School of Business, mimeo.

Agarwal, S., Lucca, D., Seru, A., and Trebbi, F. (2014). "Inconsistent Regulators: Evidence from Banking." Quarterly Journal of Economics 129.2 (2014): 889-938.

Aizenman, Joshua (1992). "Competitive Externalities and the Optimal Seigniorage." Journal of Money, Credit and Banking 24, 61-71.

Alesina, Alberto, and Allan Drazen (1991). "Why Are Stabilizations Delayed?" American Economic Review 81.5, 1170-1188.

Bordo, Michael D., and Anna J. Schwartz (1999). "Monetary Policy Regimes and Economic Performance: The Historical Record." In John Taylor and Michael Woodford (Eds.), Handbook of Macroeconomics (vol. I, pp. 149-234) Elsevier.

Buiter, Willem, and Ebrahim Rahbari (2012). "The European Central Bank as Lender of Last Resort for Sovereigns in the Eurozone." Journal of Common Market Studies 50.s2, $6-35$.

Caballero, Ricardo J., Takeo Hoshi, and Anil K. Kashyap (2008). "Zombie Lending and Depressed Restructuring in Japan.” American Economic Review 98.5, 1943-1977.

Casella, Alessandra (1992). "Participation in a Currency Union." American Economic Review 82.4, 847-863.

Ciavoliello, L. G., Ciocchetta, F., Conti, F. M., Guida, I., Rendina, A. and Santini, G. (2016). "What's the Value of NPLs?" Notes on Financial Stability and Supervision, Bank of Italy 3, 1-8.

Dinger, Valeriya, Sven Steinkamp, and Frank Westermann (2014). "The Tragedy of the Commons and Inflation Bias in the Euro Area." Open Economies Review 25.1, 71-91.

Drechsler, Itamar, Thomas Drechsel, David Marques-Ibanez, and Philipp Schnabl (2016). "Who borrows from the Lender of Last Resort?" Journal of Finance 71.5, 1933-1974.

Eichengreen, Barry (1990). "One Money for Europe? Lessons from the US Currency Union." Economic policy 5.10, 117-187.

Friedman, Milton, and Anna Schwartz (1963). A Monetary History of the United States. Princeton University Press.

Louzis, Dimitrios P., Angelos T. Vouldis, and Vasilios L. Metaxas (2012). "Macroeconomic and Bank-Specific Determinants of Non-performing Loans in Greece: A Comparative Study of Mortgage, Business and Consumer Loan Portfolios." Journal of Banking \& Finance 36.4, 1012-1027.

Nyborg, Kjell G. (2017). "Central Bank Collateral Frameworks." Journal of Banking \& Finance $76,198-214$.

Peek, Joe, and Eric S. Rosengren (2005). "Unnatural Selection: Perverse Incentives and the Misallocation of Credit in Japan." American Economic Review 95.4, 1144-1166. 
Sinn, Hans-Werner (2003). "Risktaking, Limited Liability, and the Competition of Bank Regulators." FinanzArchiv: Public Finance Analysis 59.3, 305-329.

Sinn, Hans-Werner, and Timo Wollmershäuser (2012). "Target Loans, Current Account Balances and Capital Flows: The ECB's Rescue Facility." International Tax and Public Finance 19.4, 468-508.

Sinn, Hans-Werner (2014). The Euro Trap: On Bursting Bubbles, Budgets, and Beliefs. Oxford University Press.

Tamura, Kentaro. and Evangelos Tabakis (2013). "The Use of Credit Claims as Collateral for Eurosystem Credit Operations," ECB Occasional Paper 148.

Tornell, A. and F. Westermann (2012). "Europe Needs a Federal Reserve," New York Times, June 20 .

Von Hagen, Jürgen, and Ralph Süppel (1994). "Central Bank Constitutions for Federal Monetary Unions." European Economic Review 38.3, 774-782. 


\section{$8 \quad$ Appendix}

\subsection{Voting procedures}

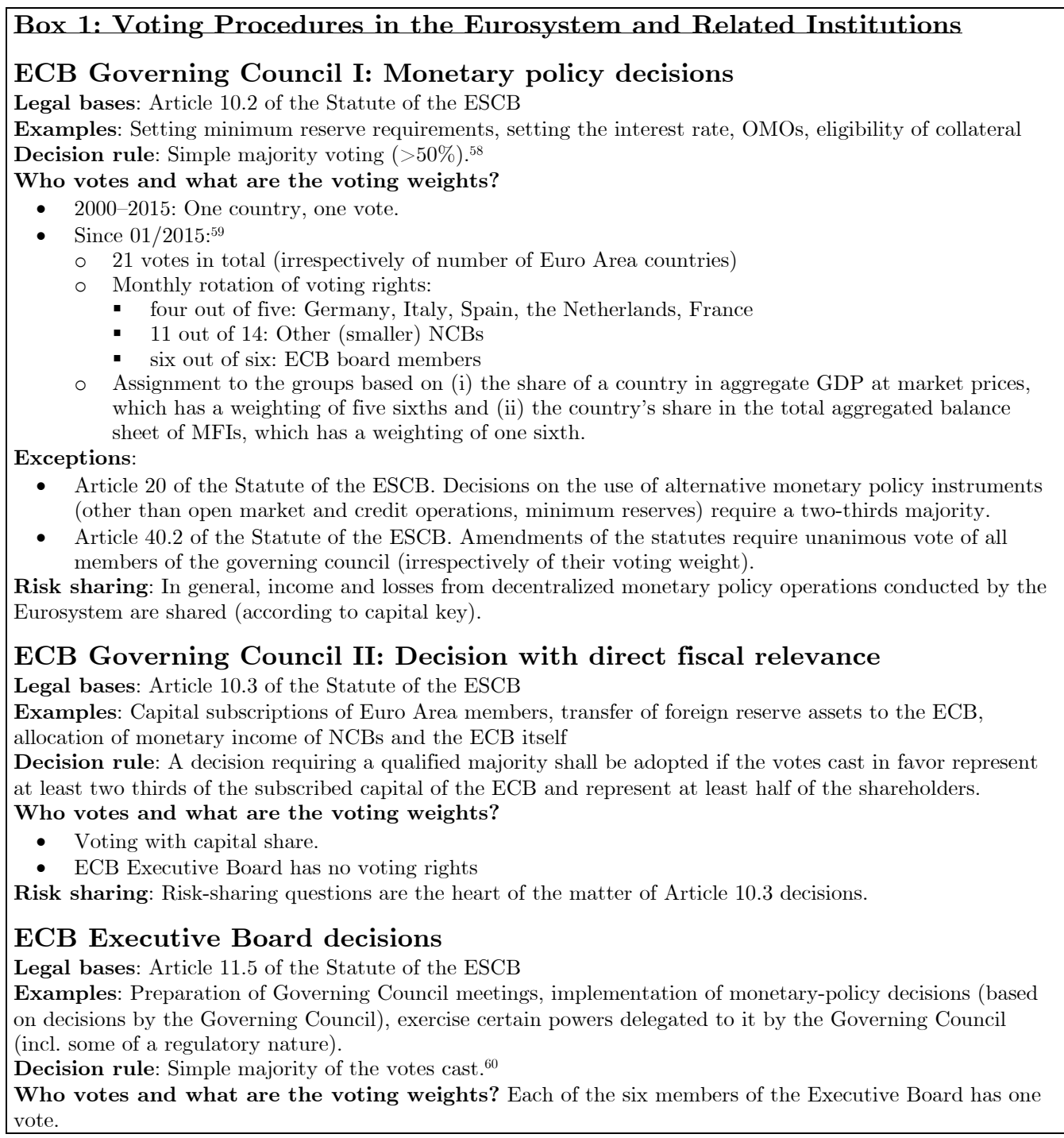

58 The president of the ECB has the casting vote if a tie occurs.

59 Based on a decision of the Council of the European Union in 2003: This followed the Governing Council's earlier decision, taken on 18 December 2008, to continue with the current voting regime in the Governing Council until the number of NCB governors in the Governing Council exceeds 18. This happened when Lithuania joined the EA in 2015.

60 The President has the casting vote in case of a tie 


\section{Supervisory Board decisions}

Legal bases: Article 6 of the Rules of procedure of the supervisory board. ${ }^{61}$ Article 26(6) of Council Regulation (EU) No 1024/2013. ${ }^{62}$

Examples: Based on its supervision, the ESBR makes proposals to authorize or withdraw banking licenses. It also decides on additional capital or provisioning requested from critical banks.

Decision rule:

- Simple majority voting $(>50 \%) .^{63}$

- No legal decision-making powers of its own; Board submits draft decisions to ECB Governing Council. Governing Council can reject supervisory board decisions with a simple majority (nonobjection principle).

Who votes and what are the voting weights?

- One member, one vote.

- Members: $\circ$ Chair \& vice-chair - four representatives of the ECB

- one representative from each NCA in the participating EU member states

- Objection decisions follow voting weight scheme of the Governing Council (see above)

\section{ECB Supervisory Board mediation panel}

Legal bases: Article 25(5) of Council Regulation (EU) No 1024/2013. ${ }^{64}$ Article 7 of Regulation (EU) No $673 / 2014 .^{65}$

Examples: Resolves differences by the competent authorities of participating member states regarding an objection of the ECB Governing Council to a draft decision by the Supervisory Board.

Decision rule: Simple majority voting $(>50 \%) .{ }^{66}$

Who votes and what are the voting weights? One country, one vote. ${ }^{67}$

\section{National Central Banks: Nonmonetary policy decisions}

Legal bases: Article 14.4 of the Statute of the ESCB, Agreement on Net Financial Assets (ANFA), Statues of the national central banks ${ }^{68}$

Examples: ELA, and other ANFA holdings

Decision rule:

- Decided by each country according the rules of the respective NCB's decision-making body. In the case of the NCBs of Ireland and Germany, for example, decisions need a simple majority of the board members. ${ }^{69}$

- Nonobjection principle. Governing Council can object NCB decisions with a two-thirds majority. Who votes and what are the voting weights? Objection decisions follow voting weight scheme of the Governing Council (see above)

Risk sharing: No risk sharing. On "responsibility and liability" of the respective NCB.

Other decisions of the NCBs: Proposing country-specific collateral criteria, issuance of bank notes, solvency of small banks (decided by each country according the rules of the respective NCA's decision-making body). ${ }^{7}$

\section{ESM - Board of Governors}

Legal bases: Article 4 of the Treaty establishing the European Stability Mechanism, 2012.

Examples: Granting ESM financial assistance, choice of instruments, choice of conditionality

Decision rule:

- Most important decisions (see above): Mutual agreement (unanimity of the members participating in the vote). ${ }^{71}$

- Less important decisions (technical terms of accession of a new ESM member, Auditing questions, choice of director and chair, etc.): qualified majority $(>80 \%)$

Who votes and what are the voting weights?

- 19 ESM members (each member of the respective shareholder government)

- $\quad$ Voting rights according to capital share

61 Rules of Procedure of the Supervisory Board of the ECB, OJ L 182, 21.6.2014, p. 56.

62 Council Regulation (EU) No 1024/2013, 15 October 2013, conferring specific tasks on the ECB concerning policies relating to the prudential supervision of credit institutions. 
63 Except where otherwise provided by Art 26(7) Regulation (EU) No 1024/2013. For example, the adoption of new regulations calls for a qualified majority. The necessary qualified majority follows Art. 16(4) of TEU and is clarified in Article 13c of the decision of the ECB of 22 January 2014 amending Decision ECB/2004/2 of 19 February 2004 adopting the Rules of Procedure of the ECB ("from 1 November 2014, decisions shall be deemed adopted when at least $55 \%$ of the Supervisory Board members representing at least $65 \%$ of the total population, cast a vote in favor. A blocking minority must include at least the minimum number of Supervisory Board members representing $35 \%$ of the total population, plus one member, failing which the qualified majority shall be deemed attained"). Further "Each of the four ECB representatives appointed by the Governing Council shall have a weight equal to the median weight of those of the representatives of the national competent authorities of participating Member States, as calculated on the basis of the method laid down in the Annex. (v) The votes of the Chair and the Vice-Chair shall be weighted zero and shall count only towards the definition of the majority as far as the number of the members of the Supervisory Board is concerned." In the case of a tie, the chair has the casting vote.

64 Council Regulation (EU) No 1024/2013, 15 October 2013 conferring specific tasks on the ECB concerning policies relating to the prudential supervision of credit institutions.

65 Regulation (EU) No 673/2014 of the ECB, 2 June 2014, concerning the establishment of a Mediation Panel and its Rules of Procedure (ECB/2014/26).

66 In the event of a tie, the most senior member in terms of office has the casting vote (if two or more members have an equal standing in terms of office, the oldest member has the casting vote).

67 "This panel shall include one member per participating Member State, chosen by each Member State among the members of the Governing Council and the Supervisory Board, and shall decide by simple majority, with each member having one vote." (Council Regulation (EU) No 1024/2013, 15 October 2013)

68 In the case of Ireland, for instance, the legal bases for ELA is provided by the Central Bank and Financial Services Authority of Ireland Act 2003. Section 5B(d) states that the powers of the Bank include the provision of "loans and other kinds of financial accommodation to credit institutions and other persons on the security of such assets and on such terms and conditions as the Board considers appropriate."

69 The legal basis for Ireland provides again the Central Bank and Financial Services Authority of Ireland Act 2003, Schedule 1, section 32. "A decision supported by a majority of the votes cast at a meeting of the Board at which a quorum is present is the decision of the Board." In Germany, this is governed in $\S 7(5)$ of the Gesetz über die Deutsche Bundesbank, October 1992.

70 For instance, Germany's Federal Financial Supervisory Authority (BaFin) decides by simple majority voting to grant a banking license (Rules of procedure of the BaFin board of directors, $\S 3$ (2)). The solvency of small banks, on the other hand, is decided by the German Bundesbank's board of directors, albeit also with a simple majority (governed in $\S 7(5)$ of the Gesetz über die Deutsche Bundesbank, October, 1992).

71 In an emergency, a simplified $85 \%$ majority rule can be applied. This is possible whenever the "Commission and the ECB both conclude that a failure to urgently adopt a decision to grant or implement financial assistance [fi] would threaten the economic and financial sustainability of the Euro Area." (Article 4(4) of the ESM treaty). 


\subsection{Data Used in the Evergreening Regression Analysis}

\begin{tabular}{|c|c|c|}
\hline Variable & Definition / Question & Source \& Code \\
\hline $\begin{array}{l}\text { EG (Micro-level evergreening } \\
\text { index) }\end{array}$ & $\begin{array}{l}\text { A dummy variable, taking the value } 1 \text { if credit } \\
\text { constraints for new loans got more restrictive than for } \\
\text { old loans, zero otherwise }\left(\mathrm{EG}_{\mathrm{i}}=1\left[\mathrm{NL}_{\mathrm{i}}>0 \mathrm{~L}_{\mathrm{i}}\right]\right) \text {. }\end{array}$ & WES $01 / 2017$ \\
\hline NL (New loans) & $\begin{array}{l}\text { See question 11b of subsection } 8.4 \text { of the data } \\
\text { appendix. }\end{array}$ & $\begin{array}{l}\text { WES 01/2017 } \\
\left(\mathrm{sq} \_201701 \_2\right)\end{array}$ \\
\hline OL (Old loans) & See question 11c of subsection 8.4 of the data appendix. & $\begin{array}{l}\text { WES 01/2017 } \\
\left(\mathrm{sq} \_201701 \_3\right)\end{array}$ \\
\hline EA (Euro Area dummy) & $\begin{array}{l}\text { A dummy variable, taking the value } 1 \text { if respondent is } \\
\text { lives in a Euro Area member country, zero otherwise. }\end{array}$ & \\
\hline $\begin{array}{l}\text { BD (Banking Distress } \\
\text { dummy) }\end{array}$ & $\begin{array}{l}\text { A dummy variable, taking the value } 1 \text { if NPLs } \\
\text { increased according to respondents, zero otherwise. See } \\
\text { question 11a of subsection } 8.4 \text { of the data appendix. }\end{array}$ & $\begin{array}{l}\text { WES 01/2017 } \\
(\text { sq_201701_1) }\end{array}$ \\
\hline Credit constraints & $\begin{array}{l}\text { "At present, to what extent is the supply of bank } \\
\text { credit to firms in this country constrained by bank- } \\
\text { specific factors (for example banks' health or banking } \\
\text { regulation)?" [not constrained, moderately constrained, } \\
\text { strongly constrained] }\end{array}$ & $\begin{array}{l}\text { WES 01/2017 } \\
\text { (cstrcred) }\end{array}$ \\
\hline Present Economic Situation & $\begin{array}{l}\text { "The country s general situation regarding the overall } \\
\text { economy (present judgment)" [good/satisfactory/bad] }\end{array}$ & $\begin{array}{l}\text { WES 01/2017 } \\
\text { (gson) }\end{array}$ \\
\hline Interest rates, short-term & $\begin{array}{l}\text { "Expected interest rates by the end of the next six } \\
\text { months (short-term rates / three-month money market } \\
\text { rates)" [higher, about the same, lower] }\end{array}$ & $\begin{array}{l}\text { WES } 01 / 2017 \\
\text { (irst) }\end{array}$ \\
\hline Interest rates, long- term & $\begin{array}{l}\text { "Expected interest rates by the end of the next six } \\
\text { months (long-term rates / government bonds with } 10 \\
\text { and more years of maturity)" [higher, about the same, } \\
\text { lower] }\end{array}$ & $\begin{array}{l}\text { WES } 01 / 2017 \\
\text { (irlt) }\end{array}$ \\
\hline Expected growth & $\begin{array}{l}\text { "The country s general situation regarding the overall } \\
\text { economy (from now on: expected situation by the end } \\
\text { of the next six months)" [good, satisfactory, bad] }\end{array}$ & $\begin{array}{l}\text { WES 01/2017 } \\
\text { (gsof) }\end{array}$ \\
\hline $\begin{array}{l}\text { Problem variables on } \\
\text { competitiveness, government } \\
\text { policy, insufficient demand, } \\
\text { inflation, foreign debts, public } \\
\text { deficits, corruption, trade } \\
\text { policy, capital shortage }\end{array}$ & $\begin{array}{l}\text { "Please try to assess the importance of the following } \\
\text { problems the economy of your country is facing at } \\
\text { present" [very important, important, not so important] }\end{array}$ & $\begin{array}{l}\text { WES 04/2016 } \\
\text { (ep01-ep11) }\end{array}$ \\
\hline
\end{tabular}




\subsection{WES Questionnaire}

Figure 9: Excerpt from the WES-survey
11. WES Special Question on Credit
a. Since 2008 , how has the share of non-performing loans changed in your country?

Increased unchanged decreased

b. Since 2008 , how has the banks attitude to approve new business loans changed?
more restrictive
unchanged
less restrictive
$\square$
$\square$

c. Since 2008 , how has the banks attitude to roll over, or extend the maturity, on existing loans changed?
more restrictive
unchanged
less restrictive

d. Since 2012, how has the supervision of banks changed the ability to roll over non-performing loans?
More difficult
unchanged
less difficult

Source: World Economic Survey, ifo Institute for Economic Research, January 2017. 


\subsection{Other Data}

\begin{tabular}{|c|c|c|c|}
\hline Variable & Definition & Source \& Code & Notes \\
\hline $\begin{array}{l}\text { NPLs } \\
\text { (official) }\end{array}$ & $\begin{array}{l}\text { Bank NPLs to total } \\
\text { gross loans }(\%) .\end{array}$ & $\begin{array}{l}\text { World Bank WDI } \\
\text { (FB.AST.NPER.ZS) }\end{array}$ & $\begin{array}{l}\text { Total gross loans include } \\
\text { nonperforming loans before } \\
\text { provisioning. }\end{array}$ \\
\hline $\begin{array}{l}\text { ECB capital } \\
\text { shares }\end{array}$ & $\begin{array}{l}\text { ECB capital shares } \\
\text { recalculated to reflect } \\
\text { actual voting shares }\end{array}$ & $\begin{array}{l}\text { ECB } \\
\text { (decision } \\
\text { ECB/2013/17) }\end{array}$ & $\begin{array}{l}\text { Recalculation accounts for } \\
\text { capital of the EU's non-Euro } \\
\text { Area NCBs without a seat in } \\
\text { the governing council. Capital } \\
\text { shares are updated every five } \\
\text { years or when the number of } \\
\text { EU member countries } \\
\text { changes. }\end{array}$ \\
\hline GDP & $\begin{array}{l}\text { Nominal gross domestic } \\
\text { product }\end{array}$ & $\begin{array}{l}\text { Eurostat } \\
\text { (nama_10_gdp) }\end{array}$ & \\
\hline $\begin{array}{l}\text { Normalized } \\
\text { Banzhaf- } \\
\text { power }\end{array}$ & $\begin{array}{l}\text { Share of possible voting } \\
\text { coalitions in which one } \\
\text { of the group members } \\
\text { has the pivotal vote } \\
\text { relative to all possible } \\
\text { (randomly drawn) } \\
\text { coalitions }\end{array}$ & $\begin{array}{l}\text { Authors' calculations } \\
\text { based on ECB capital } \\
\text { shares (see above) }\end{array}$ & $\begin{array}{l}\text { We abstract from the double- } \\
\text { majority requirement of a } 50 \% \\
\text { threshold for the number of } \\
\text { shareholders. }\end{array}$ \\
\hline $\begin{array}{l}\text { PSPP/CSPP } \\
\text { holdings }\end{array}$ & $\begin{array}{l}\text { International Securities } \\
\text { Identification Number } \\
\text { of assets bought under } \\
\text { the Expanded Asset } \\
\text { Purchase Programme of } \\
\text { the ECB }\end{array}$ & NCB websites & $\begin{array}{l}\text { No data for Portugal } \\
\text { available. Duplicates and } \\
\text { ECB purchases were dropped } \\
\text { from the sample. No } \\
\text { information on purchase } \\
\text { volumes by International } \\
\text { Securities Identification } \\
\text { Number available. }\end{array}$ \\
\hline $\begin{array}{l}\text { CSPP/PSPP } \\
\text { eligible }\end{array}$ & $\begin{array}{l}\text { International Securities } \\
\text { Identification Number } \\
\text { of assets eligible as } \\
\text { collateral in ECB } \\
\text { refinancing operations }\end{array}$ & $\begin{array}{l}\text { ECB Eligible Asset } \\
\text { Database }\end{array}$ & \\
\hline Ratings & $\begin{array}{l}\text { First-best long-term } \\
\text { issuer ratings of the } \\
\text { rating agencies S\&P, } \\
\text { Fitch, Moody's, DBRS } \\
\text { (pivotal ratings). }\end{array}$ & $\begin{array}{l}\text { Thomson Reuters } \\
\text { Datastream }\end{array}$ & $\begin{array}{l}\text { For statistics, ratings were } \\
\text { transferred to a linear } \\
\text { numerical scale }\end{array}$ \\
\hline
\end{tabular}

